\title{
Habitat Suitability of Restored Wetlands and an Investigation of Sampling Bias for Freshwater Turtles in West Virginia
}

\author{
Alissa L. Gulette \\ alg0036@mix.wvu.edu
}

Follow this and additional works at: https://researchrepository.wvu.edu/etd

Part of the Natural Resources and Conservation Commons

\section{Recommended Citation}

Gulette, Alissa L., "Habitat Suitability of Restored Wetlands and an Investigation of Sampling Bias for Freshwater Turtles in West Virginia" (2018). Graduate Theses, Dissertations, and Problem Reports. 3737. https://researchrepository.wvu.edu/etd/3737

This Thesis is protected by copyright and/or related rights. It has been brought to you by the The Research Repository @ WVU with permission from the rights-holder(s). You are free to use this Thesis in any way that is permitted by the copyright and related rights legislation that applies to your use. For other uses you must obtain permission from the rights-holder(s) directly, unless additional rights are indicated by a Creative Commons license in the record and/ or on the work itself. This Thesis has been accepted for inclusion in WVU Graduate Theses, Dissertations, and Problem Reports collection by an authorized administrator of The Research Repository @ WVU. For more information, please contact researchrepository@mail.wvu.edu. 
Habitat Suitability of Restored Wetlands and an Investigation of Sampling Bias for Freshwater Turtles in West Virginia

Alissa L. Gulette

Thesis submitted to the Davis College of Agriculture, Natural Resources, and Design At West Virginia University

In partial fulfillment of the requirements for the degree of

Master of Science

In

Wildlife and Fisheries Resources

Donald J. Brown, Ph.D., Chair

James T. Anderson, Ph.D., Co-chair

Joseph Hatton

Division of Forestry and Natural Resources

Morgantown, West Virginia

2018

Keywords: Agricultural Conservation Easement Program (ACEP), painted turtle (Chrysemys picta), snapping turtle (Chelydra serpentina), hoop-net, wildlife Copyright 2018 Alissa Gulette 


\begin{abstract}
Habitat Suitability of Restored Wetlands and an Investigation of Sampling Bias for Freshwater

Turtles in West Virginia
\end{abstract}

Alissa L. Gulette

Loss and drainage of wetlands in the United States has been remediated in part by wetland restoration on agricultural lands through the Agricultural Conservation Easement Program (ACEP), operated by the Natural Resources Conservation Service. Freshwater turtles are important components of wetland ecosystems, where they contribute to nutrient cycling, storage, and transfer between terrestrial and aquatic systems, and function as apex predators. In 2016 and 2017, we investigated use of wetlands restored through the ACEP program in West Virginia by two common freshwater turtle species, snapping turtles (Chelydra serpentina) and painted turtles (Chrysemys picta), and obtained comparative data from reference wetlands. Our objectives were to determine if abundances in ACEP wetlands differed from reference wetlands, and to delineate and quantify the effects of site-level and landscape-level habitat characteristics on turtle abundance and body condition. We found that painted turtle abundance was best predicted by surrounding wetland density and percent sand in soil, and snapping turtle abundance was best predicted by surrounding land use type. Painted turtle abundance was higher in restored compared to reference wetlands, but there was no significant difference in abundance of snapping turtles. The results of this study indicate that ACEP wetland habitat for our two focal freshwater turtle species is similar to surrounding wetlands associated with agricultural land. Our study also indicates that for wildlife that use wetland complexes, such as many freshwater turtles and amphibians, restoration of wetlands through the ACEP program likely improves habitat quality of the landscape where they occur by increasing the number of, and reducing the distance among, wetland habitat patches. During this study, we also investigated the influence of hoop-net trap size on number and size of captures for comparatively large (snapping turtle) and small (painted turtle) freshwater turtle species. We trapped turtles at 16 ACEP and 16 reference sites throughout West Virginia, with each site sampled for 5 consecutive days using $50.91-\mathrm{m}$ diameter and 5 0.76-m diameter baited hoop-net traps. Larger diameter traps captured more snapping turtles and smaller diameter traps captured more painted turtles. Mean carapace length was greater in larger diameter traps for both species, but this result was possibly influenced by the ability of the smallest painted turtles to escape through the mesh of the larger traps. This study indicates that hoop-net trap diameter can substantially influence both number and size distribution of captures, and thus trap size is an important sampling design consideration for freshwater turtle research and monitoring using hoop-net traps. 


\section{ACKNOWLEDGEMENTS}

I thank the Natural Resources Conservation Service for funding and providing logistical support for this project. I am grateful to the landowners of all of the Agricultural Conservation Easement Program wetlands for not only welcoming me onto their properties, but for their interest in my research. I thank my advisor Dr. Brown, co-chair Dr. Anderson, and committee member Mr. Hatton for their guidance these past two year of learning. I also thank my friends and family for their love and support throughout, particularly Sally, Albert, Jessica, Rachel, Maria, Adam, and my dad. Most importantly I want to thank my mom. 
TABLE OF CONTENTS

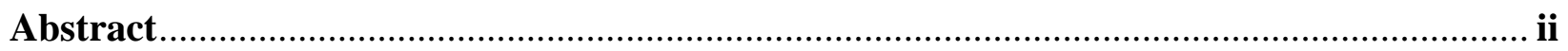

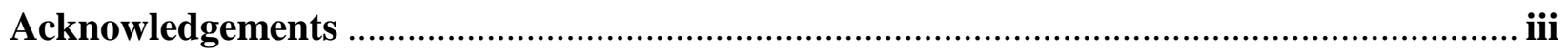

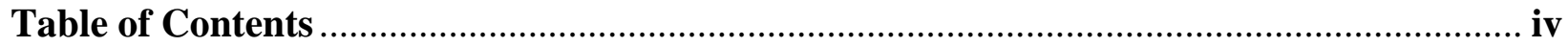

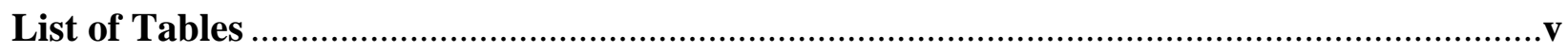

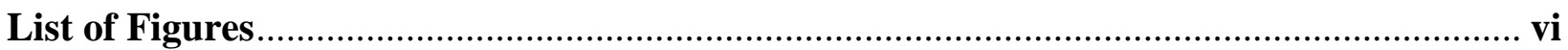

Chapter 1: Habitat Suitability of Restored Wetlands for Freshwater Turtles in West

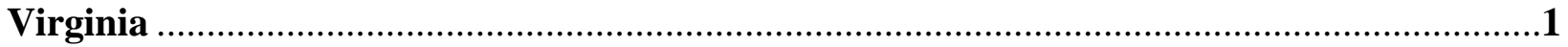

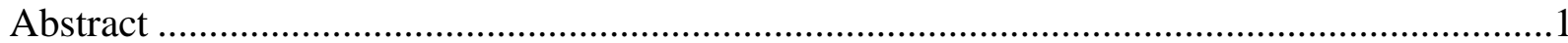

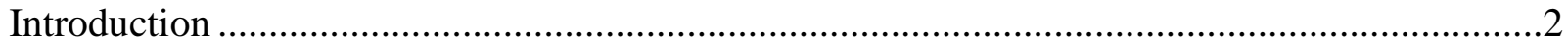

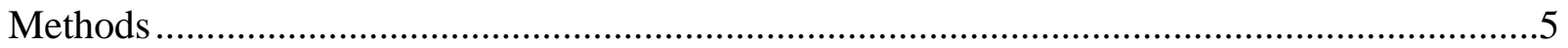

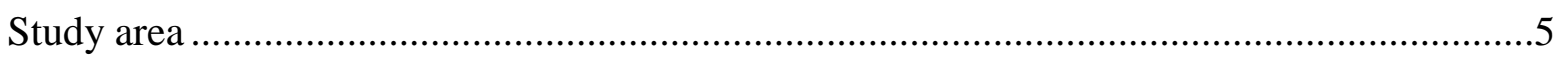

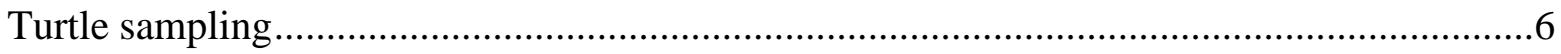

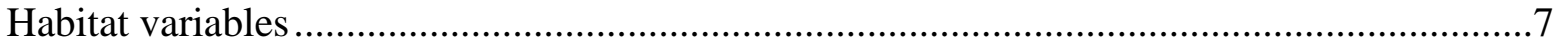

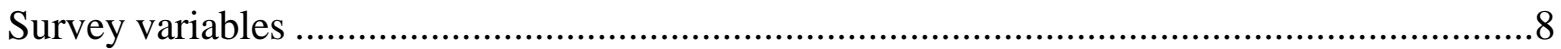

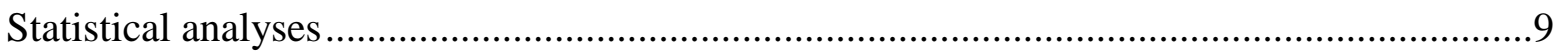

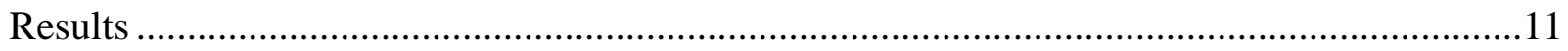

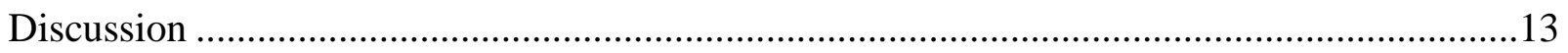

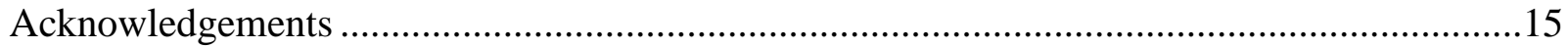

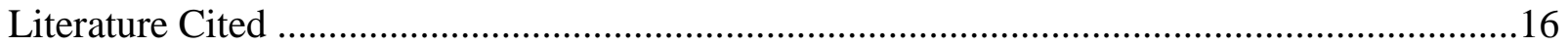

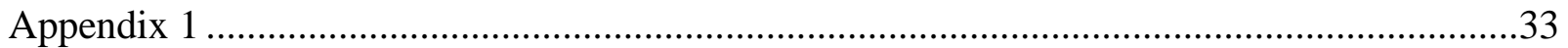

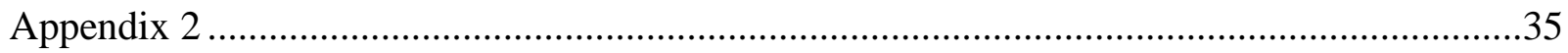

Chapter 2: Influence of Hoop-net Trap Diameter on Capture Success and Size Distribution of Comparatively Large and Small Freshwater Turtles ………..........................................37

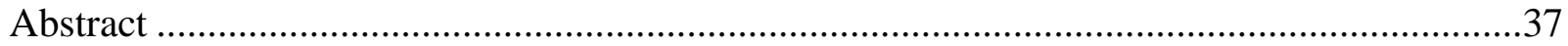

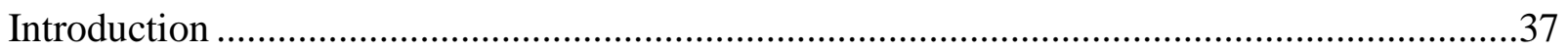

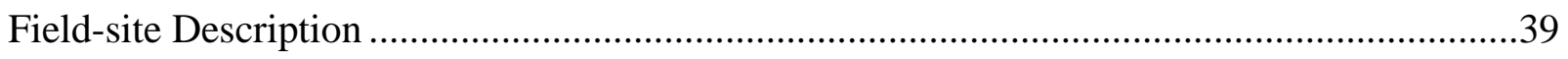

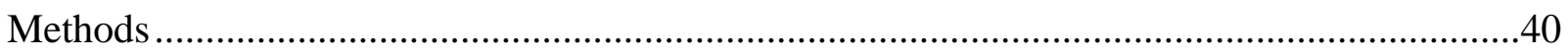

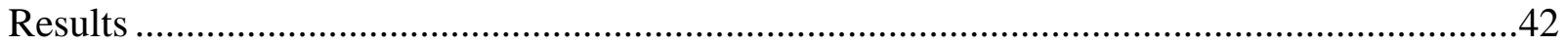

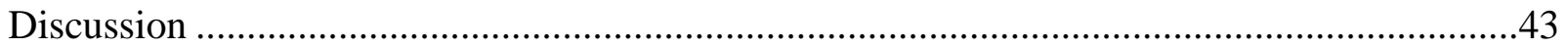

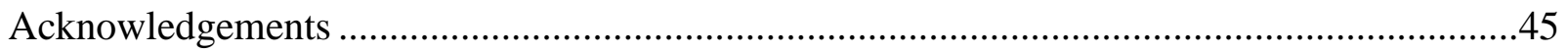

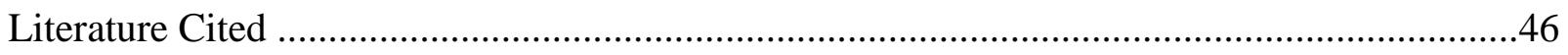




\section{LIST OF TABLES}

Table 1-1. Model selection results for habitat and sampling variables tested as covariates for snapping turtle (Chelydra serpentina) and painted turtle (Chrysemys picta) abundance $(\lambda)$, detection probability (p), and Body Condition Index (BCI) at restored and reference wetlands in West Virginia, USA. Variables shown include mean daily water temperature (temp), dissolved oxygen in water (do), \% canopy cover (canopy), \% sand in soil (soil), day of year (DOY), trap day (trap), dominant land use type in the surrounding 1,000 m (buffer), and number of wetlands in the surrounding 1,000 m (count). We compared models using model weights based on Akaike Information Criterion corrected for small-sample bias (AICcwt). With the exception of null models (.), only candidate models with a AICcwt $\geq 0.01$ are shown here.

Table 2-1. Summary data for number and mean size of Snapping Turtles (Chelydra serpentina), Painted Turtles (Chrysemys picta), and Painted Turtles with a straight line carapace width (SCW) $>8.0 \mathrm{~cm}$ captured in comparatively large $(0.91 \mathrm{~cm})$ and small $(0.76 \mathrm{~cm})$ diameter hoop-net traps. For this study, we sampled 32 ponds in West Virginia, with each pond sampled using 5 large and 5 small hoop-net traps. Data include total number of captures, mean number and standard deviation of captures per pond, and mean and standard deviation of straight line carapace length (SCL) among ponds. Unique individuals were included in both trap size data sets if they were captured in both trap sizes. $P$-values represent the results of paired randomization test. 


\section{LIST OF FIGURES}

Figure 1-1. Counties in West Virginia, USA containing the 32 wetlands used in the study to assess habitat suitability of wetlands restored through the Agricultural Conservation Easement Program (ACEP) for two common freshwater turtles, snapping turtles (Chelydra serpentina) and painted turtles (Chrysemys picta). The counties included Barbour, Berkeley, Greenbrier, Jefferson, Mason, Pendleton, Preston, and Upshur.

Figure 1-2. Correlation biplot from a redundancy analysis (RDA) used to assess differences in habitat characteristics between wetlands restored through the Agricultural Conservation Easement Program (ACEP) and reference wetlands in West Virginia, USA. Habitat variables that are further from the intercept and closer to the $\mathrm{X}$-axis are more closely associated with restored () and reference (+) wetlands, respectively. .28

Figure 1-3. Predicted detection probability ( $\mathrm{p}$ ) of snapping turtles (Chelydra serpentina) as aededed function of (a) trapping day (i.e., number of trapping days that have occurred) when day of year is held at the mean and (b) day of year when trapping day is held at day 3 , and $\mathrm{p}$ of painted turtles (Chrysemys picta) as a function of (c) mean daily water temperature, for a study assessing habitat suitability of wetlands restored through the Agricultural Conservation Easement Program (ACEP) for freshwater turtles in West Virginia, USA.

Figure 1-4. Association between dominant land use type within 1,000 $\mathrm{m}$ of wetlands and abundance of snapping turtles (Chelydra serpentina) in West Virginia, USA. We sampled 16 wetlands restored through the Agricultural Conservation Easement Program (ACEP) and 16 proximal reference wetlands. Dominant surrounding land use type was derived from the 2011 National Land Cover Database (NLCD).

Figure 1-5. Predicted Body Condition Index (BCI) of snapping turtles (Chelydra serpentina) based on \% sand in soil (a), and predicted BCI of painted turtles (Chrysemys picta) based dominant land use type within 1,000 m of wetlands (b), for a study assessing habitat suitability of wetlands restored through the Agricultural Conservation Easement Program (ACEP) for freshwater turtles in West Virginia, USA.

Figure 1-6. Predicted abundance of painted turtles (Chrysemys picta) based on (a) number of wetlands within $1,000 \mathrm{~m}$ of sampled wetlands when $\%$ sand in soil is held at the mean value, and (b) \% sand in soil when number of wetlands within 1,000 $\mathrm{m}$ of sampled wetlands is held at the mean value, for a study assessing habitat suitability of wetlands restored through the Agricultural Conservation Easement Program (ACEP) for freshwater turtles in West Virginia, USA. 
Figure 2-1. Size class distribution for (A) Snapping Turtles (Chelydra serpentina) and (B) Painted Turtles (Chrysemys picta) captured in comparatively large $(0.91 \mathrm{~cm})$ and small $(0.76 \mathrm{~cm})$ diameter hoop-net traps. For this study, we sampled 32 ponds in West Virginia, with each pond sampled using 5 large and 5 small hoop-net traps. Dotted lines represent the size distribution curves based on a fifth-degree polynomial. 


\title{
Chapter 1: Habitat Suitability of Restored Wetlands for Freshwater Turtles in West Virginia
}

\author{
Abstract Substantial historical drainage of wetlands in the United States has been \\ remediated in part by wetland restoration on agricultural lands through the Agricultural \\ Conservation Easement Program (ACEP), operated by the Natural Resources Conservation
} Service. While many studies have assessed use and habitat suitability of created and restored wetlands for birds and amphibians, few studies have focused on reptiles. Freshwater turtles are particularly important components of wetland ecosystems, where they contribute to nutrient cycling, storage, and transfer between terrestrial and aquatic systems, and function as apex predators. In 2016 and 2017, we investigated use of wetlands restored through the ACEP program in West Virginia by two common freshwater turtle species, snapping turtles (Chelydra serpentina) and painted turtles (Chrysemys picta), and obtained comparative data from reference wetlands. Our objectives were to determine if abundances in ACEP wetlands differed from reference wetlands, and to delineate and quantify the effects of site-level and landscape-level habitat characteristics on turtle abundance and body condition. At each wetland, we sampled turtle populations using baited hoop-net traps and measured potentially important habitat characteristics, including wetland depth, water quality, canopy cover, emergent plant cover, dominant aquatic vegetation type, presence of potential prey, and presence of basking surfaces. We used a geographic information system to estimate two site-level variables, wetland size and percent sand in soil, and two landscape-level variables, dominant surrounding land use type and surrounding wetland density. Painted turtle abundance was best predicted by surrounding wetland density and percent sand in soil, and snapping turtle abundance was best predicted by surrounding land use type. Painted turtle abundance was higher in restored compared to 
reference wetlands, but there was no significant difference in abundance of snapping turtles. We found that ACEP wetland habitat for our two focal freshwater turtle species is on par with surrounding wetlands associated with agricultural land. Our study also indicates that for wildlife that use wetland complexes, such as many freshwater turtles and amphibians, restoration of wetlands through the ACEP program likely improves habitat quality of the landscape where they occur by increasing the number of, and reducing the distance among, wetland habitat patches.

\section{Introduction}

Over $50 \%$ of naturally-occurring wetlands in the United States (U.S.) have been drained since European settlement (Dahl 1990). Prior to the 1970s, the removal of wetlands was supported by federal agencies, which promoted conversion to agricultural land (Vileisis 1997). The Clean Water Act of 1977 was the first piece of legislation that offered protection of remaining wetlands in the U.S. (National Research Council 2001). Beginning in 1987, a "no net loss" of wetlands policy was recommended by the U.S. Environmental Protection Agency, and the policy was adopted as federal policy in 1989 (Mitsch and Gosselink 2000; Robertson 2000; Vileisis 1997). The "Swampbuster" provision in the 1985 Farm Bill removed incentives for farmers to farm converted wetlands (Brady 2000). Then, to facilitate restoration of wetlands on private land in the U.S., the Wetlands Reserve Program (WRP) was created as part of the Farm Bill of 1990. The WRP provided funding to restore wetlands and pay easement fees to private landowners to facilitate restoration of farmland back to wetlands (Natural Resources Conservation Service [NRCS] 2014). The WRP was absorbed into the Agricultural Conservation Easement Program (ACEP) with the Agricultural Act of 2014. 
The goal of wetland restoration projects completed through the ACEP program is to return wetlands to their pre-disturbance condition and restore their functional integrity (NRCS 2010). This includes restoring and maintaining the appropriate hydrology, hydric soil, native vegetation, and ecosystem services of wetlands (NRCS 2010). Important ecosystem services sought through restoring wetlands include water filtration and recharge, nutrient recycling, and flood mitigation (Facelli and Pickett 1991; Costanza et al. 2008; Ballantine and Tanner 2010). Wetland sediments, vegetation, periphyton, and algae are responsible for removing and retaining nitrogen and phosphorus, two nutrients often sourced from agricultural runoff that can be detrimental in large quantities to aquatic systems (Reddy et al. 1999; Ballantine and Tanner 2010). Invertebrates also play an integral role in nutrient cycling by decomposing plant litter in wetlands, influencing primary productivity and prey composition (Knight and Gibbons 1968; Anderson et al. 2000; Gingerich et al. 2015). Wetlands also function as permanent or temporary habitat for a wide variety of vertebrates, including many fish, amphibian, reptile, and mammal species (Gibbs 1993; Tiner 1996; Babbitt and Tanner 2000; Semlitsch and Bodie 1998; Keddy et al. 2009).

Wetland restoration goals are generally assessed by quantifying wetland area at the landscape level, as well as assessing the quality of individual wetlands (EPA 2002). Traditional functional assessments focused on hydrology, biogeochemical processes, and physical habitat of the wetlands; ability to support plants and wildlife was a separate assessment (EPA 1998). Regarding their value to wildlife, contemporary wetland assessments often focus on use by waterfowl or amphibians (Leschisin et al. 1992; McKinstry and Anderson 2002; Petranka et al. 2003). Freshwater turtles are important members of wetland communities. They contribute to nutrient cycling, storage, and transfer between terrestrial and aquatic systems (Dreslik et al. 
2005; Sterrett et al. 2015), and serve as apex predators in these systems (Ernst 1986; Rowe and Parsons 2000; Spotilla and Bell 2008).

Despite their importance, few studies have investigated freshwater turtle use of created or restored wetlands. In particular, studies comparing turtle populations and habitat characteristics between restored and reference wetlands are generally lacking. Palis (2007) captured 3 turtle species in a wetland in Illinois within 1-4 years of restoration, and Weller (1995) documented 6 turtle species using a wetland in Florida within 5 years of restoration. Hughes et al. (2016) sampled 8 created wetlands and found that snapping turtle (Chelydra serpentina) abundance was positively correlated with large wetlands with little vegetation, and that Midland painted turtle (Chrysemys picta marginata) abundance was positively associated with small wetlands with abundant vegetation. Interestingly, they also found that juveniles of both species were found more often in shallower ponds with more vegetation than those used by adults. Dudley et al. (2015) found that restored streams with riparian wetlands in the southeastern Piedmont had greater abundance and diversity of turtle species than reference streams. Similarly, Nowalk (2010) found that restored streams in the North Carolina Piedmont had a greater abundance of turtles than natural streams, and characterized the natural areas as exhibiting greater habitat degradation. In addition, Benson et al. (2018) found species richness and abundance of freshwater turtles were similar between restored and reference wetlands in the St. Lawrence Valley of New York. Also in New York, mitigated wetlands were created adjacent to preexisting wetlands to compensate for loss of habitat for state-threatened Blanding's turtles (Emydoidea blandingii; Kiviat et al. 2000). During the first active period following construction, 10 of 16 radiotracked Blanding's turtles were documented using the created wetlands in spring, and all 11 of the radiotracked females nested at the created wetlands (Kiviat et al. 2000). Blanding's turtles 
using these created wetlands were associated with less cover and warmer waters than the adjacent natural wetlands (Hartwig and Kiviat 2007).

The previous studies indicate that freshwater turtles readily colonize created and restored wetlands, and that restoration of degraded environments benefits turtle species. However, comparative data from pre-existing local wetlands is needed to gauge the habitat quality of created and restored wetlands. The purpose of this study was to assess the suitability of wetlands restored through the WRP/ACEP programs as habitat for two common and widely distributed freshwater turtle species, snapping turtles and painted turtles. The objectives of this study were to: 1) determine if abundance of the turtle species differed between restored and reference wetlands; 2) identify important wetland habitat characteristics associated with abundance of each species; and 3) quantify relationships between the important wetland habitat characteristics and abundance to help guide future wetland restoration efforts.

\section{Methods}

Study area

We conducted this study at 32 wetlands spread across 8 counties in West Virginia, USA (Figure 1). Sixteen of the wetlands were restored through the ACEP, and the other 16 were corresponding reference wetlands. We selected reference wetlands that were near ACEP wetlands and were of similar size and surrounding land use (i.e., forested or agriculture). Reference wetlands were located 0.1-5 km from their corresponding ACEP wetlands (mean = $1.3 \mathrm{~km} ; \mathrm{SE}=0.34)$. All wetlands were located on private land, typically adjacent to agricultural 
land, with the exception of an ACEP and reference wetland located on a state wildlife management area and one ACEP wetland located on publicly-accessible land owned by the Audubon Society. The ACEP wetlands were restored between 1996 and 2011, and all were used for agriculture prior to restoration. Ages of reference wetlands were unknown. Site information and locations are provided in Appendix 1.

None of the wetlands had apparent surface connections to flowing water. Estimated wetland area ranged from $0.012-8.865 \mathrm{ha}($ mean $=0.472 \mathrm{ha} ; \mathrm{SE}=0.279)$. Wetland edges were typically covered with cattail (Typha spp.), sedges (Carex spp.), rushes (Juncus spp.), rice cutgrass (Leersia oryzoides), or arrowhead (Sagittaria spp.). We detected bluegill sunfish (Lepomis macrochirus) and channel catfish (Ictalurus punctatus) in most of the wetlands. In addition to the focal species of this study (i.e., snapping turtles and painted turtles), we captured low numbers of 4 additional turtle species, including eastern spiny softshell (Apalone spinifera), eastern musk turtle (Sternotherus odoratus), red-eared slider (Trachemys scripta elegans), and northern red-bellied cooter (Pseudemys rubriventris).

Turtle sampling

We sampled turtle populations from 16 July - 9 September 2016 (11 ACEP and 11 reference wetlands) and 3 June - 15 July 2017 (5 ACEP and 5 reference wetlands). We sampled each wetland for 5 consecutive days, using 10 baited hoop-net traps set around the perimeter of each wetland at $3-10 \mathrm{~m}$ intervals, depending on wetland size (Brown et al. 2011a). At each wetland, we used 5-0.76 $\mathrm{m}$ and 5-0.91 $\mathrm{m}$ diameter hoop-net traps, and alternated between the two trap sizes. All hoop-net traps were ca. $1.8 \mathrm{~m}$ long, and included 3 steel hoops and a single mouth with 
a circular throat (Memphis Net and Twine County, Memphis, TN). Traps were held taut using two wood posts connected to the terminal hoops, and mouths were held open by tightening, then knotting, the rope that opens them. This design allowed our traps to float and did not require that a ground stake be used to keep the mouth open. We placed flotation devices in all traps to prevent drowning of captures. We baited traps with a half-can of sardines in oil, placed in plastic bottles containing holes to allow for scent dispersal but not bait consumption (Ernst 1965, Jensen 1998, Mali et al. 2012). We checked traps and changed bait daily.

All captured turtles were identified, sexed, measured, marked using unique individual carapace notches (Cagle 1939), and released. We measured straight line carapace length (SCL) and width, plastron length and width, and body depth to the nearest $1.0 \mathrm{~mm}$ using calipers (Haglof, Madison, MS). We weighed individuals to the nearest $10 \mathrm{~g}$ using spring scales (Pesola, Baar, Switzerland). We determined sex using secondary sexual characteristics (Ernst and Lovich 2009).

Habitat variables

We included wetland type (i.e., restored or reference) as a categorical variable. We estimated wetland size using 2016 National Agriculture Imagery Program (NAIP) aerial imagery and a geographic information system (GIS; ESRI 2014). We estimated water depth at the deepest point of each wetland using a meter stick. We quantified vegetation characteristics by sampling 10 random points on the perimeter of each wetland. We estimated canopy cover (\%) at each point using a spherical densiometer. We used a $1 \mathrm{~m}^{2}$ frame to estimate emergent plant cover (\%) and dominant vegetation type (i.e., algae, floating plants, submerged plants, emergent plants). In 
addition, we visually estimated total emergent plant cover $(\%)$ for each wetland. We measured $\mathrm{pH}$, dissolved oxygen $(\mathrm{mg} / \mathrm{L})$, and conductivity $(\mathrm{uS} / \mathrm{cm})$ at each point using a YSI Professional Plus meter (YSI Incorporated, Yellow Springs, OH). We recorded presence of coarse woody debris and other potential basking surfaces (e.g., rocks) observed in the water. In addition, we recorded the presence of fish, amphibians, invertebrates, and other sources of prey captured in hoop net traps or observed in the wetland.

To account for the potential influence of surrounding land use on turtle abundance in wetlands, we created 100 and 1,000 m buffers around each site, and classified dominant land use type within the buffers using the 2011 National Land Cover Database (NLCD; Homer et al. 2015). Land cover classes for our sites included developed/open space, deciduous forest, pasture/hay, and cultivated crops. With the 1,000 $\mathrm{m}$ buffers around each site, we also calculated the number of individual wetlands using the National Wetlands Inventory (NWI) database to assess if surrounding wetland density was associated with turtle abundance (USFWS 2018). In addition, average percent sand in soil of each site was estimated using the Soil Survey Geographic Database (SSURGO), at 6 - 32 m resolution (NRCS 2016). Sand content influences both soil moisture and strength, which are important components of turtle nesting habitat quality (Christens and Bider 1987; Feaga et al. 2013; Frye et al. 2017)

Survey variables

We recorded mean daily water temperature during the sampling period at each wetland using HOBO Pendant Temperature Data Loggers (model UA-001-68; Onset Computer Corporation, Pocasset, MA). We attached a single logger to a trap ca. $0.2 \mathrm{~m}$ below the surface of the water, 
and recorded water temperature at $1 \mathrm{hr}$ intervals for the duration of the trapping period. To compute mean daily water temperature, we averaged the water temperatures using the $24 \mathrm{hr}$ clock. We recorded day of year (DOY) to account for potential seasonal differences in detection probability, and trapping day to account for potential decreased probability of capture as trapping progressed through the 5-day period (Brown et al. 2011a).

Statistical analyses

We assessed if wetland characteristics differed by wetland type (i.e., restored or reference) using a redundancy analysis (RDA), which is an extension of principal components analysis (PCA) to include explanatory variables (Legendre and Legendre 2012). Specifically, for RDA each response variable is regressed on each explanatory variable and then a PCA is performed on the matrix of fitted values (McCune and Grace 2002). We standardized the response variables (i.e., zero mean and unit variance) because they were recorded on different scales. We tested for a habitat-treatment effect using a permutation test with 10,000 replications $(\alpha=0.05)$. We visually assessed relations between individual wetland characteristics and wetland type using a correlation biplot, where angles between the habitat variables, and between habitat variables and wetland type, reflect their correlations (Borcard et al. 2011).

We used $N$-mixture models to estimate abundance of painted turtles and snapping turtles at the 32 wetlands, and to model abundance-habitat relationships. $N$-mixture models use both spatial and temporal replication of count data to jointly estimate abundance and detection probability $(p)$, and thus they explicitly account for observed numbers being a product of both ecological and observational processes (Royle 2004a). We chose to use the $N$-mixture class of 
models, rather than capture-recapture models, because $N$-mixture models have less stringent data requirements and can accommodate sites with small populations, and sites with few or no recaptures (Kéry and Royle 2016). Recaptures were low for snapping turtles (7.5\% of total captures), so we used a standard binomial $N$-mixture model with a Poisson distribution (Royle $2004 a$ ). Recaptures were higher for painted turtles (29.3\% of total captures), and we took advantage of this information by using a multinomial $N$-mixture model that included a removal sampling observation process (Royle 2004b).

To delineate important covariates for $p$ and abundance, we used a model selection approach based on the Akaike Information Criterion corrected for small-sample bias (AICc; Anderson and Burnham 2002). We performed the model selection in two steps, first selecting a top model for $p$ without abundance covariates, and then including the important $p$ covariates in the abundance covariate model selection. We included linear relationships for all variables, as well as quadratic relationships for $\mathrm{pH}$ and dissolved oxygen based on preliminary analyses of the raw data, which indicated abundance relationships with these variables may be quadratic. For each model selection performed, we selected the model with the lowest AICc score as the top model. In addition to delineating important covariates for $p$ and abundance, we also explicitly tested whether abundance of each species differed between restored and reference wetlands. For this test, we included the covariates from the top $p$ model, and a categorical covariate for wetland type. We used Wald tests to determine if wetland type was a significant predictor of abundance (Royle and Dorazio 2008). To ensure that our data adequately fit the distribution assumptions of $N$-mixture models, we used the model diagnostic quasi-coefficient of variation (QCV), and assumed the model estimates were not strongly biased when the absolute value of the relative 
bias was $<0.50$ (Duarte et al. 2018). Our top snapping turtle and painted turtle model had a QCV value of 0.34 and 0.24 , respectively.

In addition to using abundance as a metric of habitat quality, we also investigated if body condition of painted turtles and snapping turtles was influenced by wetland type and habitat variables. A Body Condition Index (BCI) for unique individuals was computed by first creating a regression using log weight and $\log \mathrm{SCL}$, computing expected log weight with the regression equation, and then using the difference between expected and observed log weight as the BCI (Green 2001; Litzgus et al. 2008). We used Generalized Linear Models (GLM) and AICc model selection to determine the top models explaining the BCI scores, and performed Wald tests to determine if wetland type was a significant predictor of BCI. We inferred statistical significance at $\alpha=0.05$. We performed statistical analyses using program $\mathrm{R}$ (version 3.3.2; The $\mathrm{R}$ Foundation for Statistical Computing, Vienna, Austria). We used the package vegan (version 2.5-1) for the RDA, lme4 (version 1.1-13) for model diagnostics, unmarked (version 0.11-0) for $N$-mixture models, stats (version 3.3.2) for GLMs, and AICmodavg (version 2.1-0) for model selection.

\section{Results}

We captured 98 unique snapping turtles, including 60 and 38 in restored and reference wetlands, respectively. Unique individuals ranged from 0 to 18 (mean $=3.75 ; \mathrm{SE}=0.94)$ and 0 to 7 (mean $=2.375 ; \mathrm{SE}=0.59)$ in restored and reference wetlands, respectively. We captured 283 unique painted turtles, including 199 and 84 in restored and reference wetlands, respectively. Unique individuals ranged from 0 to $114($ mean $=12.5 ; \mathrm{SE}=3.13)$ and 0 to $41($ mean $=5.38 ; \mathrm{SE}=1.34)$ 
in restored and reference wetlands, respectively. Both species were captured at 14 sites, only snapping turtles at 13 sites, only painted turtles at 2 sites, and no turtles at 3 sites.

There was no significant community-level difference in habitat variables between restored and reference wetlands (adjusted $\mathrm{R}^{2}=0.006 ; \mathrm{P}=0.618$ ), and no individual variables were strongly associated with wetland type (Figure 2). Minimum and maximum values for restored and reference wetlands displayed much overlap (Appendix 2).

For snapping turtles, the top $p$ model included DOY and trapping day as covariates. Both variables showed a weak negative correlation with $p$ (Figure $3 a$ and $3 b$ ). Wetland type was not a significant predictor of abundance $(\mathrm{P}=0.523)$. The top abundance model included dominant land use type within 1,000 $\mathrm{m}$ as a covariate (Table 1). Predicted abundance was greatest when the dominant land use type was cultivated crops (Figure 4). Wetland type was also not a significant predictor of BCI $(\mathrm{P}=0.355)$. The top $\mathrm{BCI}$ model included percent sand in soil as a covariate (Table 1), which was negatively correlated with BCI (Figure 5a).

For painted turtles, the top $p$ model included mean daily water temperature as a covariate. The variable showed a strong positive correlation with $p$ (Figure $3 \mathrm{c}$ ). Wetland type was a significant predictor of abundance $(\mathrm{P}<0.0001)$, with greater abundance in restored wetlands $($ mean $=23.49 ; 95 \% \mathrm{CI}=[19.76,27.92])$ than reference wetlands $($ mean $=7.63 ; 95 \% \mathrm{CI}=[6.10$, 9.54]). The top abundance model included wetland density within 1,000 $\mathrm{m}$ and percent sand in soil as covariates (Table 1). Predicted abundance was positively correlated with both variables (Figure 6a and 6b, respectively). Wetland type was not a significant predictor of BCI $(\mathrm{P}=0.769)$. The top BCI model included dominant land use type within 1,000 m (Table 1), where predicted BCI was greatest when the dominant land use type was cultivated crops (Figure 5b). 


\section{Discussion}

Wetlands in West Virginia restored through the ACEP program had similar habitat characteristics as surrounding wetlands on private agricultural land, and both wetland types provided suitable habitat for two widespread turtle species. Thus, our study supports previous findings that some freshwater turtle species can persist in agriculturally-dominated landscapes, provided the landscapes contain suitable wetland complexes (e.g., Bowne et al. 2006; Failey et al. 2007; Brown et al. 2011b). Our study also supports previous research that indicated freshwater turtles naturally colonize created and restored wetlands (Weller 1995; Palis 2007).

Based on the site and landscape variables we tested, the strongest predictor of abundance for both species was a landscape variable. Snapping turtle abundance was highest in wetlands primarily surrounded by agriculture. This association could reflect the prevalence of nonforested, open canopy areas for nesting and thermoregulation, which is preferred by snapping turtles (Petokas and Alexander 1980; Thompson et al. 2017). In addition to surrounding agriculture influence on abundance, we found that painted turtle BCI was highest in wetlands primarily surrounded by agriculture. This association could once again reflect the prevalence of open canopy areas for thermoregulation and other metabolic activities influencing growth of turtles (Cagle 1946; Ernst 1972; Pitfield and Burger 2016). Painted turtle abundance was positively associated with surrounding wetland density. Similarly, Marchand and Litvaitis (2004) found that abundance of painted turtles was positively correlated with proximity to other wetlands. Painted turtles and many other freshwater turtles readily move among wetlands, likely to maximize habitat quality for survival, growth, and reproduction (Sexton 1959; Bowne et al. 2006; Cosentino et al. 2010). Thus, landscapes with greater availability and diversity of wetlands 
can often support more robust and healthy turtle populations (Joyal et al. 2001; Roe and Georges 2007). Mean wetland density within 1,000 m was greater for restored wetlands than reference wetlands (16.63 and 12.38, respectively), which may explain why painted turtles were more abundant in restored wetlands given that site-level habitat characteristics were similar.

In addition to these influential landscape variables, we also found a site-level variable, percent sand in soil, was associated with painted turtle abundance and snapping turtle BCI. Although painted turtles have been documented using a wide variety of soil types when nesting (Mahmoud 1968; Christens and Bider 1987), sandy soil is optimal because it is easier to dig nest cavities (Feaga et al. 2013; Frye et al. 2017). In addition, loamy sand can reduce the likelihood of hatchlings freezing and increase survival rates (Packard and Packard 1997). Thus, assuming greater reproduction or reproductive success occurs at wetlands with sandier soil, we would expect turtle abundance to be higher. However, we found that snapping turtle BCI had a weak negative correlation with percent sand in soil. We speculate that food resource availability may have been lower at sandier sites, but additional research is needed to clarify this relationship.

In summary, we found that wetlands in West Virginia restored through the ACEP program are providing suitable habitat for two freshwater turtle species. The habitat characteristics we measured did not significantly differ between restored and reference wetlands, indicating the restored wetlands likely serve as additional similar habitat, rather than as a new type of habitat, for wetland-associated wildlife species. Our study also indicates the benefits of wetland creation and restoration likely extends beyond creating a new site to be occupied. By increasing the number of habitat patches and reducing the distance between habitat patches, habitat quality of the wetland complex improves. This is not only beneficial for freshwater 
turtles, but for other wetland-associated species such as amphibians and waterfowl (Taft and Haig 2006; Petranka et al. 2007; Peterman et al. 2013; Mitchell 2016).

Acknowledgements This research was funded by the U. S. Department of Agriculture's (USDA) Natural Resources Conservation Service. This work also was supported by the USDA National Institute of Food and Agriculture, McIntire Stennis projects WVA00117 and WVA00122, and the West Virginia Agricultural and Forestry Experiment Station. J.T. Anderson was supported by the National Science Foundation under Cooperative Agreement No. OIA1458952 during manuscript preparation. We thank R. Wickiser, K. Levat, and K. Matthews for assisting with fieldwork. We are grateful to the West Virginia Division of Natural Resources, Potomac Audubon Society, and the many private landowners who graciously allowed us to use their property for several days or weeks. Capture and handling methods were approved by the West Virginia Division of Natural Resources (Permits 2016.173, 2016.174, 2017.013) and West Virginia University Institutional Animal Care Use Committee (Protocol 1603001197). Any use of trade, product, or firm names is for descriptive purposes only and does not imply endorsement by the U.S. Government. This is Scientific Article No. XXXX of the West Virginia Agricultural and Forestry Experiment Station, Morgantown, West Virginia, USA. 


\section{References}

Anderson DR, Burnham KP (2002) Avoiding pitfalls when using information theoretic methods. Journal of Wildlife Management 66:921-918

Anderson JT, Smith LM, Haukos DA (2000) Feather molt influence on diet selection of nonbreeding green-winged teal in playas. Journal of Wildlife Management 64:222-230

Babbitt KJ, Tanner GW (2000) Use of temporary wetlands by anurans in a hydrologically modified landscape. Wetlands 20:313-322

Ballantine DJ, Tanner CC (2010) Substrate and filter materials to enhance phosphorus removal in constructed wetlands treating diffuse farm runoff: a review. New Zealand Journal of Agricultural Research 53:71-95

Benson CE, Carberry B, Langen TA (2018) Public-private partnership wetland restoration programs benefit species of greatest conservation need and other wetland-associated wildlife. Wetlands Ecology and Management 26:195-211

Borcard D, Gillet F, Legendre P (2011) Numerical ecology with R. Springer, New York, New York

Bowne DR, Bowers MA, Hines JE (2006) Connectivity in an agricultural landscape as reflected by interpond movements of a freshwater turtle. Conservation Biology 20:780-791

Brady SJ (2000) Highly erodible land and Swampbuster provisions: conservation compliance and wetlands conservation provisions of the Omnibus Farm Acts of 1985, 1990, and 1996. In: Hohman WL, Halloum DJ (eds) A comprehensive review of Farm Bill contributions to wildlife conservation, 1985-2000. US Department of Agriculture, 
Natural Resources Conservation Service, Wildlife Habitat Management Institute, Washington, D.C., pp 5-17

Brown DJ, Farallo VR, Dixon JR, Baccus JT, Simpson, TR, Forstner, MRJ (2011b) Freshwater turtle conservation in Texas: harvest effects and efficacy of the current management regime. Journal of Wildlife Management 75:486-494

Brown DJ, Mali I, Forstner MRJ (2011a) No difference in short-term temporal distribution of trapping effort on hoop-net capture efficiency for freshwater turtles. Southeastern Naturalist 10:245-250

Cagle FR (1939) A system of marking turtles for future identification. Copeia 1939:170-173

Cagle FR (1946) The growth of the slider turtle, Pseudemys scripta elegans. American Midland Naturalist 36:685-729

Christens E, Bider JR (1987) Nesting activity and hatching success of the painted turtle (Chrysemys picta marginata) in southwestern Quebec. Herpetologica 43:55-65

Cosentino BJ, Schooley RL, Phillips CA (2010) Wetland hydrology, area, and isolation influence occupancy and spatial turnover of the painted turtle, Chrysemys picta. Landscape Ecology 25:1589-1600

Costanza R, Perez-Maqueo O, Martinez ML, Sutton P, Anderson SJ, Mulder K (2008) The value of coastal wetlands for hurricane protection. AMBIO 37:241-248

Dahl TE (1990) Wetland losses in the United States, 1780's to 1980's. National Wetlands Inventory, St. Petersburg, Florida 
Dreslik MJ, Kuhns AR, Phillips CA (2005) Structure and composition of a southern Illinois freshwater turtle assemblage. Northeastern Naturalist 12:173-186

Duarte A, Adams MJ, Peterson JT (2018) Fitting N-mixture models to count data with unmodeled heterogeneity: bias, diagnostics, and alternative approaches. Ecological Modeling 374:51-59

Dudley MP, Ho M, Richardson CJ (2015) Riparian habitat dissimilarities in restored and reference streams are associated with differences in the turtle communities in the southeastern Piedmont. Wetlands 35:147-157

Ernst CH (1965) Bait preferences of some freshwater turtles. Journal of the Ohio Herpetological Society 5:53

Ernst CH (1972) Temperature-activity relationship in the painted turtle, Chrysemys picta. Copeia $1972: 217-222$

Ernst CH (1986) Ecology of the turtle, Sternotherus odoratus, in Southeastern Pennsylvania. Journal of Herpetology 20:341-352

Ernst CH, Lovich JE (2009) Turtles of the United States and Canada. Johns Hopkins University Press, Baltimore, Maryland

Environmental Protection Agency [EPA] (1998) Wetland biological assessments and HGM functional assessment. U.S. EPA, Office of Water, Office of Wetlands, Oceans, and Watersheds, Washington, D.C.

Environmental Protection Agency [EPA] (2002) Wetland monitoring \& assessment: a technical framework. U.S. EPA, Office of Water, Washington, D.C. 
Environmental Systems Research Institute [ESRI] (2014) ArcGIS Release 10.3. Redlands, CA.

Facelli JM, Pickett STA (1991) Plant litter: its dynamics and effects on plant community structure. Botanical Review 57:1-32

Failey EL, McCoy JC, Price SJ, Dorcas ME (2007) Ecology of turtles inhabiting golf course and farm ponds in the western piedmont of North Carolina. Journal of the North Carolina Academy of Science 123:221-232

Feaga JB, Burger JA, Haas CA (2013) Bog turtle (Glyptemys muhlenbergii) wetland habitat: an emphasis on soil properties. Natural Areas Journal 33:404-412

Frye AB, Hardy K, Hedrick AR, Iverson JB (2017) Factors affecting nesting times in the painted turtle Chrysemys picta in Nebraska. Chelonian Conservation Biology 16:44-51

Gibbs JP (1993) Importance of small wetlands for the persistence of local populations of wetland-associated animals. Wetlands 13:25-31

Gingerich RT, Panaccione DG, Anderson JT (2015) The role of fungi and invertebrates in litter decomposition in mitigated and reference wetlands. Limnologica 54:23-32

Green AJ (2001) Mass/length residuals: measures of body condition or generators of spurious results? Ecology 82:1473-1483

Hartwig TS, Kiviat E (2007) Microhabitat association of Blanding's turtles in natural and constructed wetlands in southeastern New York. Journal of Wildlife Management $71: 576-582$

Homer CG, Dewitz JA, Yang L, Jin S, Danielson P, Xian G, Coulston J, Herold ND, Wickham JD, Megown K (2015) Completion of the 2011 National Land Cover Database for the 
conterminous United States- representing a decade of cover change information.

Photogrammetric Engineering and Remote Sensing 81:345-354

Hughes DF, Tegeler AK, Meshaka WE (2016) Differential use of ponds and movements by two species of aquatic turtles (Chrysemys picta marginata and Chelydra serpentina) and their role in colonization. Herpetological Conservation and Biology 11:214-231

Jensen JB (1998) Bait preferences of southeastern United States coastal plain riverine turtles: Fish or fowl? Chelonian Conservation and Biology 3:109-111

Joyal LA, McCollough M, Hunter Jr. ML (2001) Landscape ecology approaches to wetland species conservation: a case study of two turtle species in southern Maine. Conservation Biology 15:1755-1762

Keddy PA, Fraser LH, Solomeshch AI, Junk WJ, Campbell DR, Arroyo MTK, Alho CLJR (2009) Wet and wonderful: the world's largest wetlands are conservation priorities. BioScience 59:39-44

Kéry M, Royle JA (2016) Applied hierarchical modeling in ecology: analysis of distribution, abundance and species richness in R and BUGS. Academic Press, Waltham, Massachusetts

Kiviat E, Stevens G, Brauman R, Hoeger S, Petokas PJ, Hollands GG (2000) Restoration of wetland and upland habitat for the Blanding's turtle, Emydoidea blandingii. Chelonian Conservation and Biology 3:650-657

Knight AW, Gibbons JW (1968) Food of the painted turtle, Chrysemys picta, in a polluted river. American Midland Naturalist 80:558-562 
Legendre P, Legendre L (2012) Numerical ecology. Elsevier, Amsterdam pp 629 - 661

Leschisin DA, Williams GL, Weller MW (1992) Factors affecting waterfowl use of constructed wetlands in Northwestern Minnesota. Wetlands 12:178-183

Litzgus JD, Bolton F, Schulte-Hostedde AI (2008) Reproductive output depends on body condition in Spotted turtles (Clemmys guttata). Copeia 2008:86-92

Mahmoud IY (1968) Nesting behavior in the western painted turtle, Chrysemys picta bellii. Herpetologica 24:155-162

Mali I, Brown DJ, Forstner MRJ (2012) Switching bait as a method to improve freshwater turtle capture and recapture success with hoop net traps. Southeastern Naturalist 11:311-318

Marchand MN, Litvaitis JA (2004) Effects of habitat features and landscape composition on the population structure of a common aquatic turtle in a region undergoing rapid development. Conservation Biology 18:758-767

McCune B, Grace JB (2002) Analysis of ecological communities. MjM Software Design, Gleneden Beach, Oregon

McKinstry MC, Anderson SH (2002) Creating wetlands for waterfowl in Wyoming. Ecological Engineering 18:293-304

Mitchell JC (2016) Restored wetlands in mid-Atlantic agricultural landscapes enhance species richness of amphibian assemblages. Journal of Fish and Wildlife Management 7:490-498

Mitsch WJ, Gosselink JG (2000) Wetlands. Third Edition. John Wiley and Sons, Inc., New York, New York 
National Research Council (2001) Compensating for wetland losses under the Clean Water Act. National Academy Press, Washington, D.C.

Natural Resources Conservation Service [NRCS] (2010) Wetland restoration. United States Department of Agriculture, Washington, D.C.

Natural Resources Conservation Service [NRCS] (2014) Restoring America's wetlands: a private lands conservation success story. United States Department of Agriculture, Washington, D.C.

Natural Resources Conservation Service [NRCS] (2016) Web Soil Survey. <http://websoilsurvey.nrcs.usda.gov/>. Accessed 21 May 2018

Nowalk M (2010) The effect of stream restoration on turtle species assemblages in the piedmont region of North Carolina, USA. Thesis, Duke University

Packard GC, Packard MJ (1997) Type of soil affects survival by overwintering hatchlings of the painted turtle. Journal of Thermal Biology 22:53-58

Palis JG (2007) If you build it, they will come: herpetofaunal colonization of constructed wetlands and adjacent terrestrial habitat in the Cache River drainage of southern Illinois. Transactions of the Illinois State Academy of Science 100:177-189

Peterman WE, Anderson TL, Drake DL, Ousterhout BH, Semlitsch RD (2013) Maximizing pond biodiversity across the landscape: a case study of larval ambystomatid salamanders. Animal Conservation 17:275-285

Petokas PJ, Alexander MM (1980) The nesting of Chelydra serpentina in northern New York. Journal of Herpetology 14:239-244 
Petranka JW, Harp EM, Holbrook CT, Hamel JA (2007) Long-term persistence of amphibian populations in a restored wetland complex. Biological Conservation 138:371-380

Petranka JW, Murray SS, Kennedy CA (2003) Responses of amphibians to restoration of a southern Appalachian wetland: perturbations confound post-restoration assessment. Wetlands 23:278-290

Pitfield T, Burger J (2016) Basking habitat use and response of freshwater turtles to human presence in an urban canal of Central New Jersey. Urban Ecosystems 20:449-461

Reddy KR, Kadlec RH, Flaig E, Gale PM (1999) Phosphorus retention in streams and wetlands: a review. Critical Reviews in Environmental Science and Technology 29:83-146

Robertson MM (2000) No net loss: Wetland restoration and the incomplete capitalization of nature. Antipode 32:463-493

Roe JH, Georges A (2007) Heterogeneous wetland complexes, buffer zones, and travel corridors: landscape management for freshwater reptiles. Biological Conservation 135:67-76.

Royle JA (2004a) $\mathrm{N}$-mixture models for estimating population size from spatially replicated counts. Biometrics 60:108-115

Royle JA (2004b) Generalized estimators of avian abundance from county survey data. Animal Biodiversity and Conservation 27:3753-86

Royle JA, Dorazio RM (2008) Hierarchical modeling and inference in ecology: the analysis of data from populations, metapopulations, and communities. Academic Press, London, $\mathrm{p}$ 64 
Rowe JW, Parsons W (2000) Diet of the midland painted turtle (Chrysemys picta marginata). Herpetological Review 31:16-17

Semlitsch RD, Bodie JR (1998) Are small, isolated wetlands expendable? Conservation Biology 12:1129-1133

Sexton OJ (1959) Spatial and temporal movements of a population of the painted turtle, Chrysemys picta marginata (Agassiz). Ecological Monographs 29:113-140

Spotilla JR, Bell BA (2008) Thermal ecology and feeding of the snapping turtle, Chelydra serpentina. In: Steyermark AC, Finkler MS, and Brooks RJ (eds) Biology of the snapping turtle (Chelydra serpentina), Johns Hopkins University Press, Baltimore, Maryland, pp $71-79$

Sterrett SC, Maerz JC, Katz RA (2015) What can turtles teach us about the theory of ecological stoichiometry? Freshwater Biology 60:443-455

Taft OW, Haig SM (2006) Importance of wetland landscape structure to shorebirds wintering in an agricultural valley. Landscape Ecology 21:169-184

Thompson MM, Coe BH, Congdon JD, Stauffer DF, Hopkins WA (2017) Nesting ecology and habitat use of Chelydra serpentina in an area modified by agriculture and industrial activity. Herpetological Conservation and Biology 12:292-306

Tiner RW (1996) Current status of West Virginia's wetlands: Results of the National Wetlands Inventory. U.S. Fish and Wildlife Service, Ecological Services, Region 5, Hadley, Massachusetts 
USFWS (2018) National wetlands inventory - version 2 - surface waters and wetlands inventory. U.S. Fish and Wildlife Service, Washington, D.C.

Vileisis A (1997) Discovering the unknown landscape: A history of America's wetlands. Island Press, Washington, D.C.

Weller JD (1995) Restoration of a south Florida forested wetland. Ecological Engineering $5: 143-151$

West Virginia Department of Environmental Protection [WVDEP] (2018) Annual rainfall by county: West Virginia. WVDEP, Charleston, West Virginia 


\section{TABLES}

Table 1 Model selection results for habitat and sampling variables tested as covariates for snapping turtle (Chelydra serpentina) and painted turtle (Chrysemys picta) abundance $(\lambda)$, detection probability (p), and Body Condition Index (BCI) at restored and reference wetlands in West Virginia, USA. Variables shown include mean daily water temperature (temp), dissolved oxygen in water (do), \% canopy cover (canopy), \% sand in soil (soil), day of year (DOY), trap day (trap), dominant land use type in the surrounding 1,000 $\mathrm{m}$ (buffer), and number of wetlands in the surrounding 1,000 m (count). We compared models using model weights based on Akaike Information Criterion corrected for small-sample bias (AICcwt). With the exception of null models (.), only candidate models with a AICcwt $\geq 0.01$ are shown here.

\begin{tabular}{|c|c|c|c|c|}
\hline Species & Model structure & $\mathrm{AICc}$ & delta & AICcwt \\
\hline \multirow[t]{7}{*}{ Snapping turtle } & $\mathrm{p}($ trap + DOY) $\lambda($ buffer $)$ & 369.13 & 0 & 0.93 \\
\hline & $\mathrm{p}($ trap $+\mathrm{DOY}) \lambda($ canopy $)$ & 374.84 & 5.7 & 0.05 \\
\hline & $\mathrm{p}($ trap $+\mathrm{DOY}) \lambda(\mathrm{do})$ & 378.81 & 9.68 & 0.01 \\
\hline & $\mathrm{p}(.) \lambda()$. & 380.03 & 10.9 & 0 \\
\hline & BCI(soil) & -372.35 & 0 & 0.58 \\
\hline & $\mathrm{BCI}(\mathrm{do})$ & -367.93 & 4.42 & 0.06 \\
\hline & BCI(.) & -367.00 & 5.35 & 0.04 \\
\hline \multirow[t]{4}{*}{ Painted turtle } & $\mathrm{p}($ temp) $\lambda($ count + soil $)$ & 614.76 & 0 & 1.00 \\
\hline & $\mathrm{p}(.) \lambda()$. & 1154.62 & 539.86 & 0 \\
\hline & BCI(buffer) & -329.32 & 0 & 1.00 \\
\hline & $\mathrm{BCI}()$. & -153.0 & 176.33 & 0 \\
\hline
\end{tabular}




\section{FIGURES}

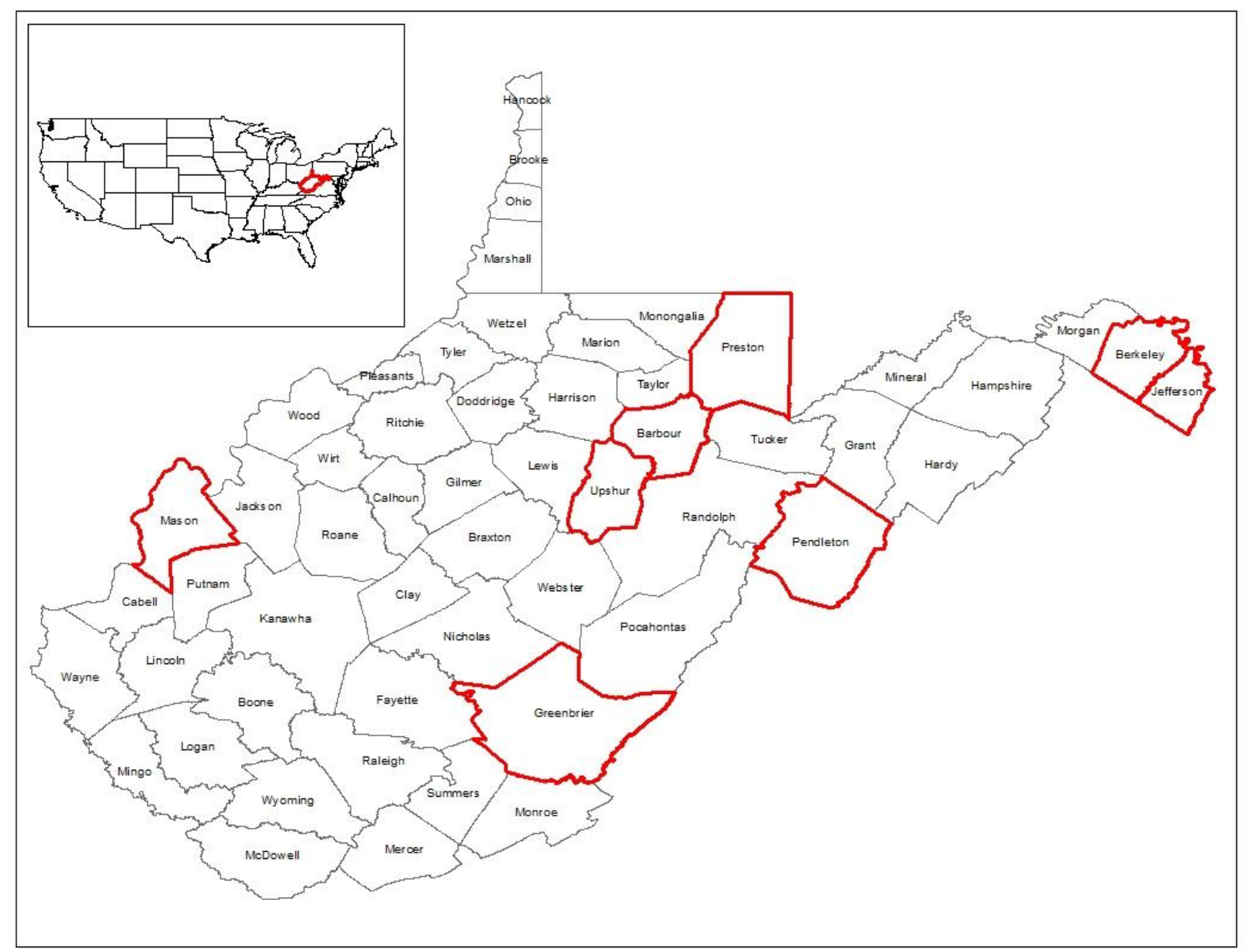

Fig. 1 Counties in West Virginia, USA containing the 32 wetlands used in the study to assess habitat suitability of wetlands restored through the Agricultural Conservation Easement Program (ACEP) for two common freshwater turtles, snapping turtles (Chelydra serpentina) and painted turtles (Chrysemys picta). The counties included Barbour, Berkeley, Greenbrier, Jefferson, Mason, Pendleton, Preston, and Upshur. 


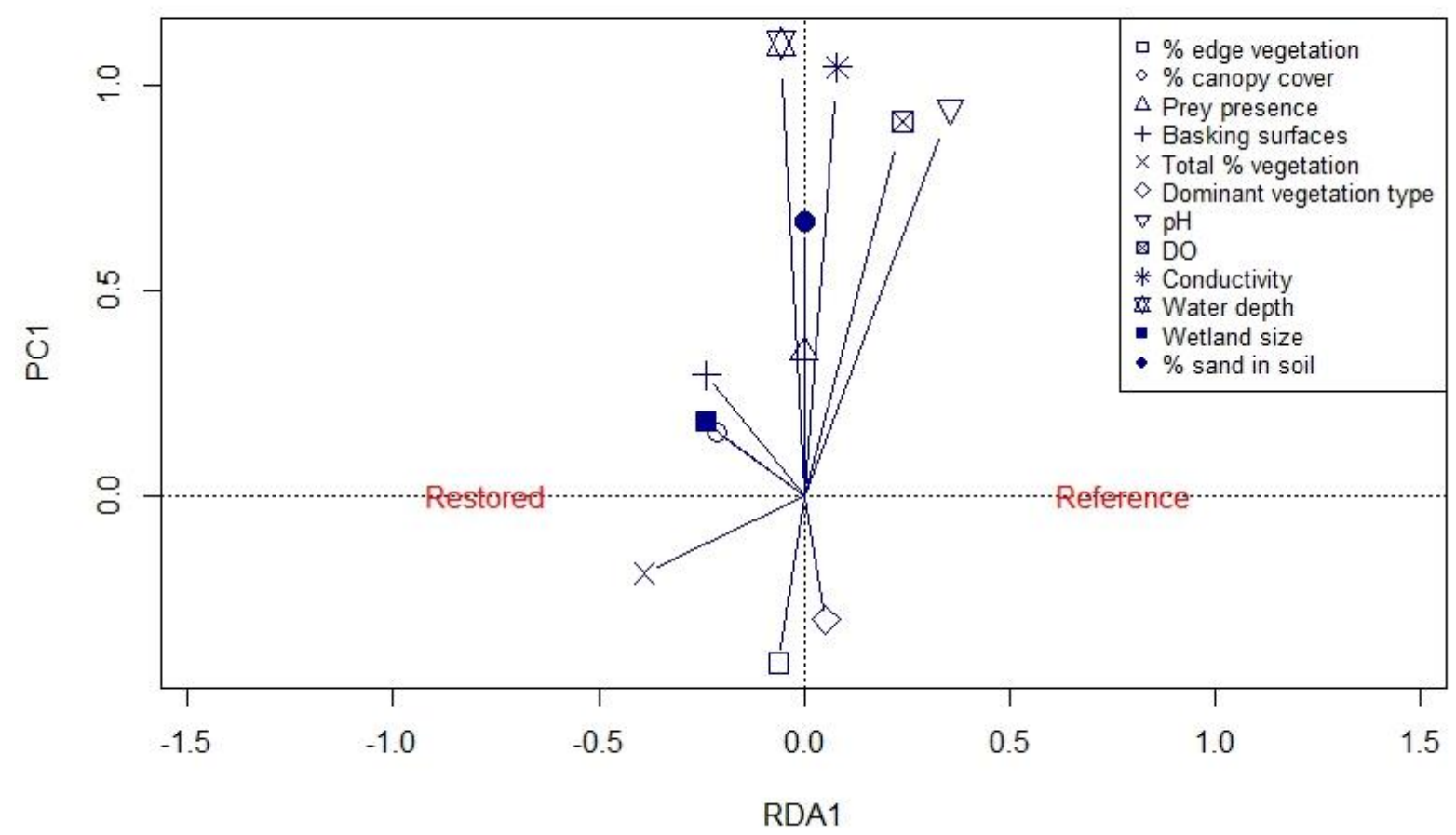

Fig. 2 Correlation biplot from a redundancy analysis (RDA) used to assess differences in habitat characteristics between wetlands restored through the Agricultural Conservation Easement Program (ACEP) and reference wetlands in West Virginia, USA. Habitat variables that are further from the intercept and closer to the X-axis are more closely associated with restored (-) and reference (+) wetlands, respectively. 

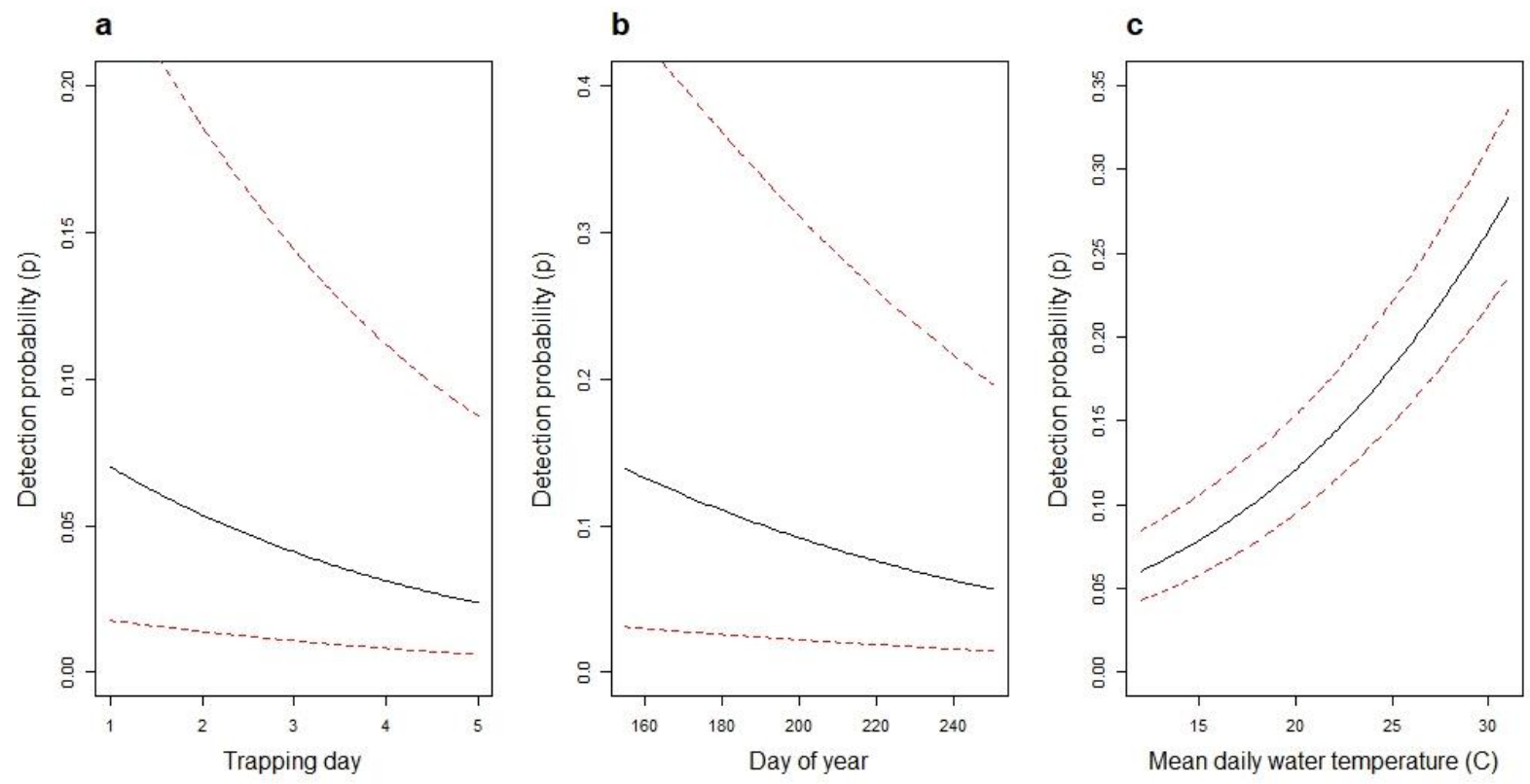

Fig. 3 Predicted detection probability (p) of snapping turtles (Chelydra serpentina) as a function of (a) trapping day (i.e., number of days trapping has occurred) when day of year is held at the mean and (b) day of year when trapping day is held at day 3, and p of painted turtles (Chrysemys picta) as a function of (c) mean daily water temperature, for a study assessing habitat suitability of wetlands restored through the Agricultural Conservation Easement Program (ACEP) for freshwater turtles in West Virginia, USA. 

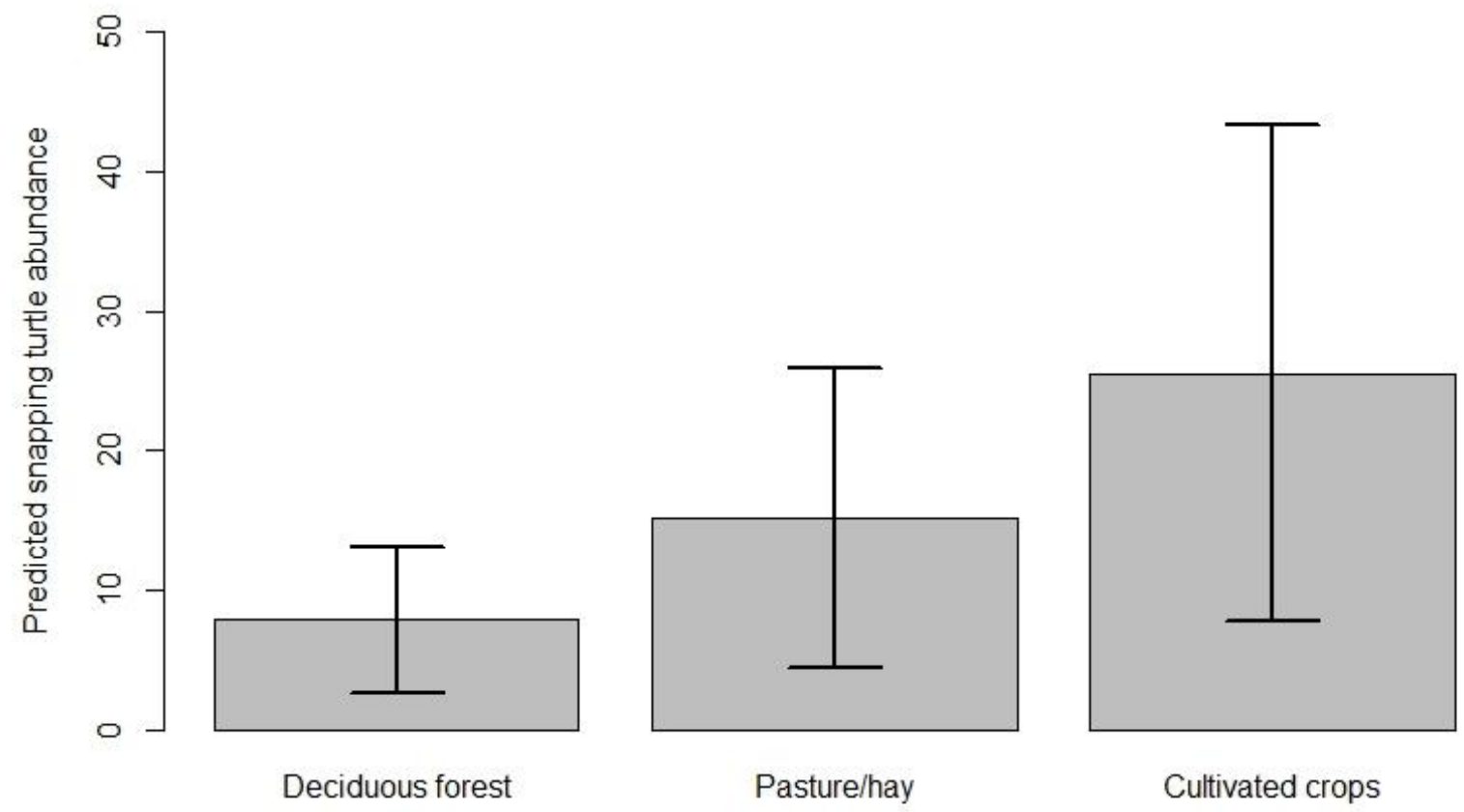

Dominant surrounding land use type

Fig. 4 Association between dominant land use type within 1,000 $\mathrm{m}$ of wetlands and abundance of snapping turtles (Chelydra serpentina) in West Virginia, USA. We sampled 16 wetlands restored through the Agricultural Conservation Easement Program (ACEP) and 16 proximal reference wetlands. Dominant surrounding land use type was derived from the 2011 National Land Cover Database (NLCD). 

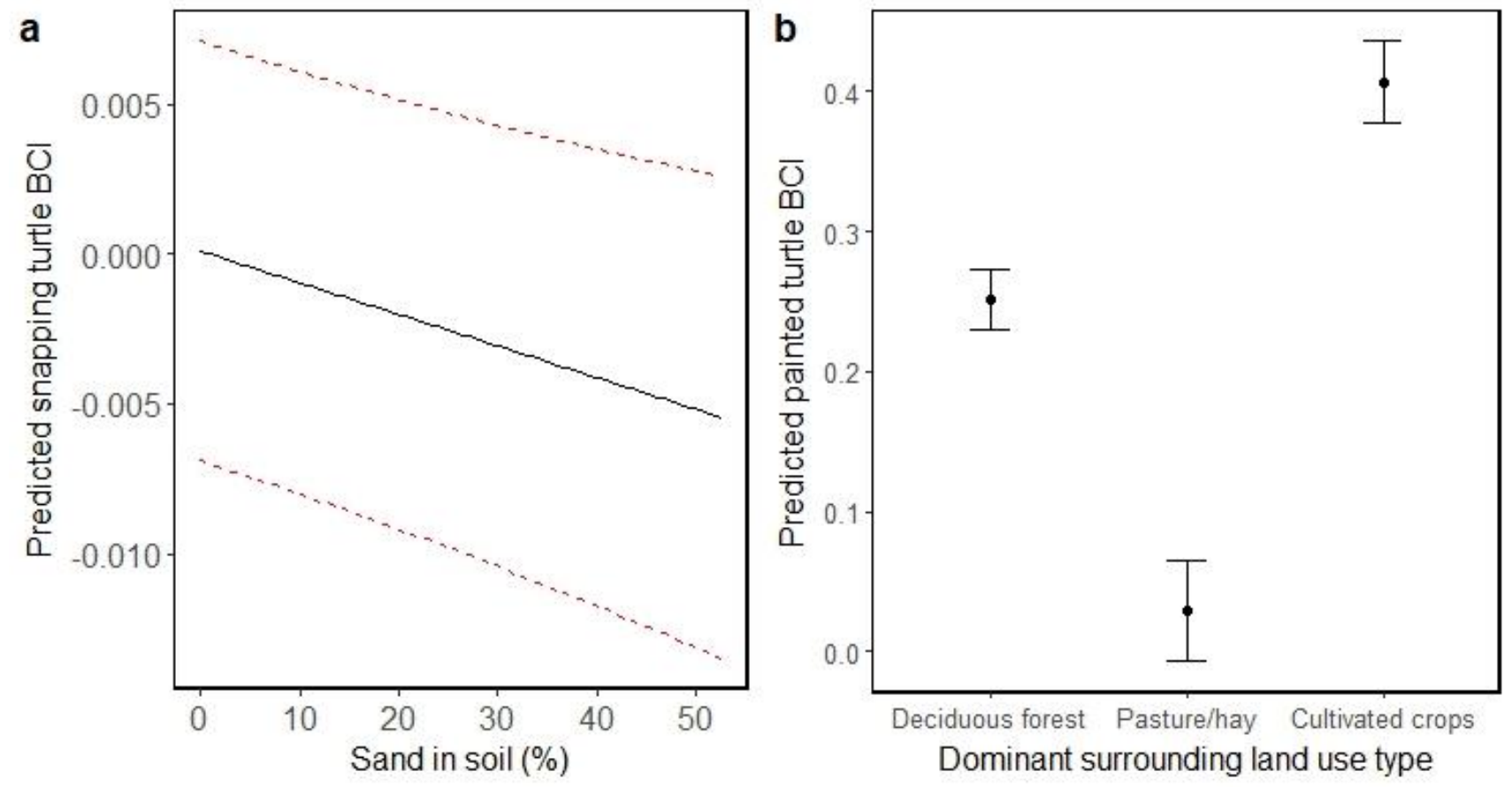

Fig. 5 Predicted Body Condition Index (BCI) of snapping turtles (Chelydra serpentina) based on $\%$ sand in soil (a), and predicted BCI of painted turtles (Chrysemys picta) based dominant land use type within 1,000 m of wetlands (b), for a study assessing habitat suitability of wetlands restored through the Agricultural Conservation Easement Program (ACEP) for freshwater turtles in West Virginia, USA. 
a

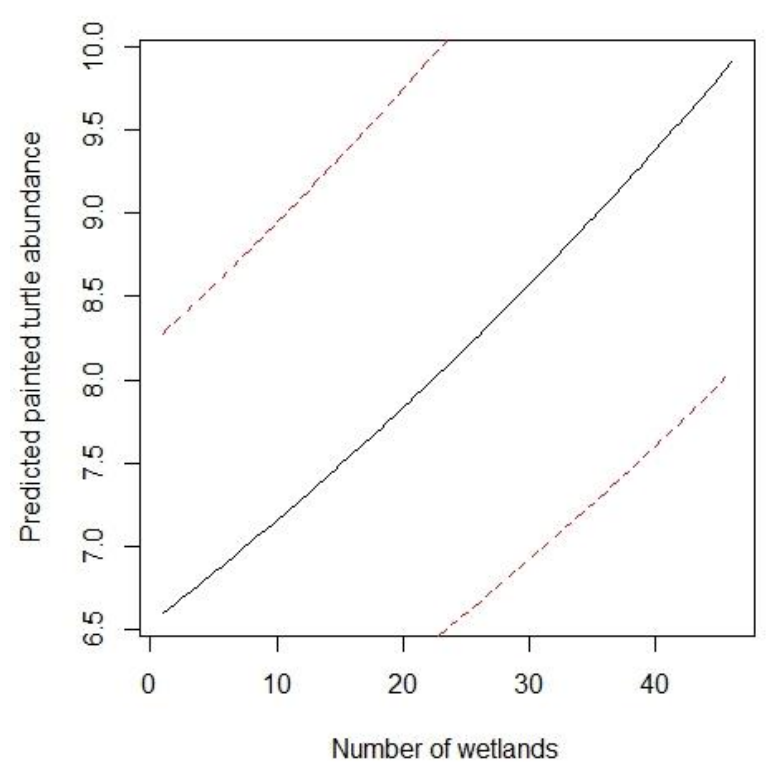

b

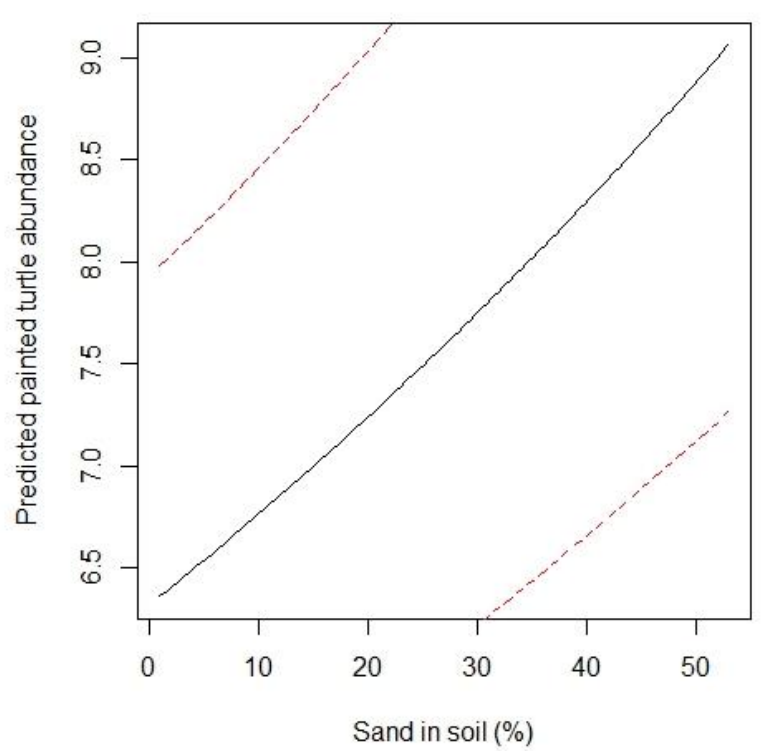

Fig. 6 Predicted abundance of painted turtles (Chrysemys picta) based on (a) number of wetlands within 1,000 m of sampled wetlands when $\%$ sand in soil is held at the mean value, and (b) \% sand in soil when number of wetlands within 1,000 $\mathrm{m}$ of sampled wetlands is held at the mean value, for a study assessing habitat suitability of wetlands restored through the Agricultural Conservation Easement Program (ACEP) for freshwater turtles in West Virginia, USA. 


\section{APPENDICES}

Appendix 1. Site information for each restored and reference wetland including county, physiogeographic region, private or public property type, estimated area (ha), year restored for ACEP sites, and mean annual rainfall (cm; WVDEP 2018), for a study assessing habitat suitability of wetlands restored through the Agricultural Conservation Easement Program (ACEP) for freshwater turtles in West Virginia, USA.

\begin{tabular}{|c|c|c|c|c|c|c|}
\hline \multirow[b]{2}{*}{ Site } & \multirow[b]{2}{*}{ County } & \multicolumn{2}{|l|}{ Physiogeographic } & & \multirow{2}{*}{$\begin{array}{c}\text { Annual } \\
\text { rainfall }(\mathrm{cm})\end{array}$} \\
\hline & & region & Property & area (ha) & restored & \\
\hline Restored wetland 1 & Berkeley & Great Valley & Public & 0.0595 & 1996 & 89.662 \\
\hline Restored wetland 2 & Barbour & Appalachian Plateau & Public & 1.0591 & 1997 & 116.586 \\
\hline Restored wetland 3 & Greenbrier & Appalachian Plateau & Private & 0.0398 & 2010 & 94.742 \\
\hline Restored wetland 4 & Jefferson & Great Valley & Private & 0.5931 & 1998 & 93.472 \\
\hline Restored wetland 5 & Jefferson & Great Valley & Private & 0.0666 & 1998 & 93.472 \\
\hline Restored wetland 6 & Mason & Appalachian Plateau & Private & 0.1165 & 1996 & 96.012 \\
\hline Restored wetland 7 & Mason & Appalachian Plateau & Private & 0.0841 & 1996 & 96.012 \\
\hline Restored wetland 8 & Mason & Appalachian Plateau & Private & 0.088 & 1996 & 96.012 \\
\hline Restored wetland 9 & Mason & Appalachian Plateau & Private & 0.0208 & 1996 & 96.012 \\
\hline Restored wetland 10 & Mason & Appalachian Plateau & Private & 0.2111 & 1996 & 96.012 \\
\hline Restored wetland 11 & Pendleton & Valley and Ridge & Private & 0.0187 & 2011 & 80.264 \\
\hline Restored wetland 12 & Preston & Alleghany Plateau & Private & 0.0404 & 1998 & 117.856 \\
\hline Restored wetland 13 & Preston & Alleghany Plateau & Private & 0.2419 & 1998 & 117.856 \\
\hline Restored wetland 14 & Preston & Alleghany Plateau & Private & 0.165 & 1998 & 117.856 \\
\hline Restored wetland 15 & Upshur & Appalachian Plateau & Private & 0.029 & 1999 & 122.174 \\
\hline Restored wetland 16 & Upshur & Appalachian Plateau & Private & 0.0488 & 1999 & 1F22.174 \\
\hline Reference wetland 1 & Berkeley & Great Valley & Private & 1.9557 & NA & 89.662 \\
\hline Reference wetland 2 & Barbour & Appalachian Plateau & Public & 8.8648 & NA & 116.586 \\
\hline Reference wetland 3 & Greenbrier & Appalachian Plateau & Private & 0.0719 & NA & 94.742 \\
\hline Reference wetland 4 & Jefferson & Great Valley & Private & 0.013 & NA & 93.472 \\
\hline Reference wetland 5 & Jefferson & Great Valley & Private & 0.1871 & NA & 93.472 \\
\hline Reference wetland 6 & Mason & Appalachian Plateau & Private & 0.0376 & NA & 96.012 \\
\hline Reference wetland 7 & Mason & Appalachian Plateau & Private & 0.0269 & NA & 96.012 \\
\hline Reference wetland 8 & Mason & Appalachian Plateau & Private & 0.0647 & NA & 96.012 \\
\hline Reference wetland 9 & Mason & Appalachian Plateau & Private & 0.4355 & NA & 96.012 \\
\hline Reference wetland 10 & Mason & Appalachian Plateau & Private & 0.0561 & NA & 96.012 \\
\hline
\end{tabular}




\begin{tabular}{lcccccc} 
Reference wetland 11 & Pendleton & Valley and Ridge & Private & 0.0115 & NA & 80.264 \\
Reference wetland 12 & Preston & Alleghany Plateau & Private & 0.2489 & NA & 117.856 \\
Reference wetland 13 & Preston & Alleghany Plateau & Private & 0.053 & NA & 117.856 \\
Reference wetland 14 & Preston & Alleghany Plateau & Private & 0.1279 & NA & 117.856 \\
Reference wetland 15 & Upshur & Appalachian Plateau & Private & 0.0395 & NA & 122.174 \\
Reference wetland 16 & Upshur & Appalachian Plateau & Private & 0.0179 & NA & 122.174 \\
\hline
\end{tabular}


Appendix 2. Site variation including mean, minimum, maximum, and mode values among overall, restored, and reference sites for each habitat variable for a study assessing habitat suitability of wetlands restored through the Agricultural Conservation Easement Program (ACEP) for freshwater turtles in West Virginia, USA.

\begin{tabular}{|c|c|c|c|c|}
\hline Habitat variable & Mean & Minimum & Maximum & Mode \\
\hline \multicolumn{5}{|l|}{ Overall } \\
\hline$\%$ edge emergent vegetation & 37.86 & 0.00 & 82.00 & NA \\
\hline$\%$ canopy & 17.48 & 0.00 & 89.90 & NA \\
\hline Prey presence & NA & NA & NA & Present \\
\hline Basking surfaces & NA & NA & NA & Absent \\
\hline$\%$ total emergent vegetation & 22.81 & 5.00 & 65.00 & NA \\
\hline Dominant vegetation type & NA & NA & NA & Emergent \\
\hline $\mathrm{pH}$ & 7.12 & 6.08 & 8.29 & NA \\
\hline Dissolved oxygen $(\mathrm{mg} / \mathrm{L})$ & 4.73 & 2.03 & 10.99 & NA \\
\hline Conductivity (uS/cm) & 203.86 & 13.71 & 650.10 & NA \\
\hline Water depth (m) & 1.16 & 0.39 & 3.30 & NA \\
\hline Surrounding land use (100 m) & NA & NA & NA & Deciduous forest \\
\hline Surrounding land use $(1,000 \mathrm{~m})$ & NA & NA & NA & Deciduous forest \\
\hline Wetland size $\left(\mathrm{m}^{2}\right)$ & 4717.04 & 115.04 & 88648.41 & NA \\
\hline$\%$ sand in soil & 24.69 & 0.00 & 52.50 & NA \\
\hline Surrounding wetlands count & 14.50 & 1.00 & 46.00 & 6.00 \\
\hline \multicolumn{5}{|l|}{ Restored wetlands } \\
\hline$\%$ edge emergent vegetation & 38.92 & 0.00 & 82.00 & NA \\
\hline$\%$ canopy & 21.66 & 0.00 & 89.90 & NA \\
\hline Prey presence & NA & NA & NA & Present \\
\hline Basking surfaces & NA & NA & NA & Present \\
\hline$\%$ total emergent vegetation & 27.19 & 5.00 & 40.00 & NA \\
\hline Dominant vegetation type & NA & NA & NA & Emergent \\
\hline $\mathrm{pH}$ & 6.96 & 6.08 & 7.84 & NA \\
\hline Dissolved oxygen $(\mathrm{mg} / \mathrm{L})$ & 4.25 & 2.42 & 9.86 & NA \\
\hline Conductivity (uS/cm) & 192.73 & 13.71 & 548.70 & NA \\
\hline
\end{tabular}




\begin{tabular}{|c|c|c|c|c|}
\hline Water depth (m) & 1.18 & 0.43 & 2.20 & NA \\
\hline Surrounding land use (100 m) & NA & NA & NA & Deciduous forest \\
\hline Surrounding land use $(1,000 \mathrm{~m})$ & NA & NA & NA & Deciduous forest \\
\hline Wetland size $\left(\mathrm{m}^{2}\right)$ & 7632.53 & 115.04 & 88648.41 & NA \\
\hline$\%$ sand in soil & 24.69 & 13.00 & 37.50 & NA \\
\hline Surrounding wetlands count & 12.81 & 2.00 & 25.00 & 6.00 \\
\hline \multicolumn{5}{|l|}{ Reference wetlands } \\
\hline$\%$ edge emergent vegetation & 36.80 & 3.00 & 65.50 & NA \\
\hline$\%$ canopy & 13.29 & 0.00 & 71.80 & NA \\
\hline Prey presence & NA & NA & NA & Present \\
\hline Basking surfaces & NA & NA & NA & Absent \\
\hline$\%$ total emergent vegetation & 18.44 & 5.00 & 65.00 & NA \\
\hline Dominant vegetation type & NA & NA & NA & Emergent \\
\hline $\mathrm{pH}$ & 7.28 & 6.50 & 8.29 & NA \\
\hline DO & 5.20 & 2.03 & 10.99 & NA \\
\hline Conductivity & 214.99 & 25.97 & 650.10 & NA \\
\hline Water depth & 1.13 & 0.39 & 3.30 & NA \\
\hline Surrounding land use (100 m) & NA & NA & NA & Pasture/hay \\
\hline Surrounding land use $(1,000 \mathrm{~m})$ & NA & NA & NA & Deciduous forest \\
\hline Wetland size $\left(\mathrm{m}^{2}\right)$ & 1801.55 & 187.15 & 10591.13 & NA \\
\hline$\%$ sand in soil & 24.69 & 0.00 & 52.50 & NA \\
\hline Surrounding wetlands count & 16.19 & 1.00 & 46.00 & 6.00 \\
\hline
\end{tabular}




\title{
Chapter 2: Influence of Hoop-net Trap Diameter on Capture Success and Size Distribution of Comparatively Large and Small Freshwater Turtles
}

\begin{abstract}
We investigated the influence of hoop-net trap size on number and size of captures for comparatively large (Chelydra serpentina [Snapping Turtle]) and small (Chrysemys picta [Painted Turtle]) freshwater turtle species. We trapped turtles at 32 ponds throughout West Virginia in the summers of 2016 and 2017, with each pond sampled for 5 consecutive days using 5 0.91-m diameter and 5 0.76-m diameter baited hoop-net traps. We captured a total of 98 and 283 unique Snapping Turtles and Painted Turtles, respectively. Larger diameter traps captured more Snapping Turtles and smaller diameter traps captured more Painted Turtles. Mean carapace length was greater in larger diameter traps for both species, but this result was possibly influenced by the ability of the smallest Painted Turtles to escape through the mesh of the larger traps. Our study indicates that hoop-net trap diameter can substantially influence both number and size distribution of captures, and thus trap size is an important sampling design consideration for freshwater turtle research and monitoring using hoop-net traps.
\end{abstract}

\section{Introduction}

Estimation of abundance and demographic structure (e.g., age or size distribution, sex ratio) is a fundamental component of population-monitoring programs (Buckland et al. 2000, Campbell et al. 2002). Many statistical methods have been developed to facilitate accurate estimates of population and community parameters, but they all rely on the data meeting the assumptions of the model to avoid biased estimates (Yoccoz et al. 2001, Tyre et al. 2003). Thus, there is strong 
interest in developing sampling techniques and protocols that minimize sampling bias (e.g., Sterrett et al. 2010, Mali et al. 2014, Brown et al. 2017).

A variety of tools and techniques exist for sampling aquatic and semiaquatic turtles (Lagler 1943, Vogt 1980), and new sampling devices continue to be developed (e.g., Lindeman 2014, Chandler et al. 2017). Passive sampling using baited hoop-net traps is one of the most commonly used approaches (Davis 1982). Compared to many other sampling devices for freshwater turtles (e.g., basking traps, fyke nets, trammels), hoop-net traps have the advantages of being lightweight, portable, requiring only one worker to assemble and deploy, and providing easily quantifiable results.

Despite their advantages, several studies have found that data obtained from hoop-net trapping can result in biased demographic and abundance estimates (Ream and Ream 1966, Koper and Brooks 1998, Tesche and Hodges 2015). However, identifying and mitigating the factors that cause biases is complicated because baited hoop-nets work by attracting individuals into the trap, and that attraction (i.e., probability of capture) can differ by species, sex, size, individual, and previous capture history (reviewed by Mali et al. 2014). One proposed solution has been to use multiple types of sampling methods to increase among and within-species representation (Koper and Brooks 1998, Sterrett et al. 2010, Tesche and Hodges 2015). This solution appears to be particularly useful for community-level studies due to large speciesspecific differences in capture probability for individual sampling methods (e.g., Gamble 2006, Sterrett et al. 2010). The advantages of using multiple types of sampling methods is less clear for population-level studies, given each method has its own sampling biases, and thus robust data sets are required to properly account for biases of each sampling method in population models. 
Regardless of the benefits and drawbacks of using multiple sampling methods, there is a need to improve our knowledge of the biases of individual sampling methods. Understanding these biases can lead to more appropriate sampling designs, and can result in more accurate estimates of population parameters by accounting for them in the sampling design or statistical models. The majority of previous research investigating hoop-net trap biases has focused on the influences of bait type, having other turtles in traps, and escape from traps (reviewed by Mali et al. 2014). Little attention has been given to capture biases resulting from size of hoop-net traps. Howell et al. (2016) determined that a miniaturized hoop-net trap was effective for sampling Clemmys guttata (Schneider) Spotted Turtle, but did not compare capture efficiency to larger hoop-net traps.

The purpose of this study was to determine if the diameter of baited hoop-net traps has a significant effect on number and size of captures for comparatively large and small aquatic turtles. We used Chelydra serpentina (Linnaeus) (Snapping Turtle) and Chrysemys picta (Schneider) (Painted Turtle) as representative species for the larger and smaller size classes, respectively. Painted Turtles included Chrysemys picta picta (Schneider) (Eastern Painted Turtle) and Chrysemys picta marginata (Aggasiz) (Midland Painted Turtle). We hypothesized that hoop-net trap diameter would have no influence on number or size of smaller turtle captures, but that number and size of larger turtle captures would be greater in larger hoop-net traps.

\section{Field-site Description}

We conducted this study at 32 ponds spread across the state of West Virginia, USA (i.e., Barbour, Berkeley, Greenbrier, Jefferson, Mason, Preston, and Upshur counties). Sixteen of the ponds were portions of restored wetlands conserved through the Agricultural Conservation 
Easement Program of the Natural Resources Conservation Service. Ponds were located on private land, typically adjacent to agricultural land, with the exception of two ponds located on a state wildlife management area and one pond located on publicly-accessible land owned by the Audubon Society. Most pond edges were generally covered with Typha spp. (cattail), Carex spp. (sedges), Juncus spp. (rushes), Leersia oryzoides L. (rice cutgrass), or Sagittaria spp. (arrowhead). Pond area ranged from $0.012-8.865$ ha $($ mean $=0.472$ ha; $\mathrm{SE}=0.279)$. All ponds contained fish populations. We detected Lepomis macrochirus (Rafinesque) (Bluegill Sunfish) at all but 4 ponds and Ictalurus punctatus (Rafinesque) (Channel Catfish) at many of the ponds. In addition to the focal species of this study (i.e., Snapping Turtles and Painted Turtles), we captured 4 additional turtle species, including Apalone spinifera (LeSueur) (Eastern Spiny Softshell), Sternotherus odoratus (Latreille) (Eastern Musk Turtle), Trachemys scripta elegans (Schoepff) (Red-eared Slider), and Pseudemys rubriventris (LeConte) (Northern Red-bellied Cooter).

\section{Methods}

We performed this study from 16 July - 9 September 2016 (22 ponds) and 3 June - 15 July 2017 (10 ponds). Each pond was trapped for 5 consecutive days, using 10 traps set around the perimeter of each pond at $3-10 \mathrm{~m}$ intervals, depending on pond size. We used 5 smaller and 5 larger diameter traps at each pond, and alternated between the two trap sizes to reduce the potential for trapping location to influence results. The hoop-net traps were ca. $1.8 \mathrm{~m}$ long, and included 3 steel hoops and a single mouth with a circular throat (Memphis Net and Twine County, Memphis, TN). The larger and smaller traps measured $0.91 \mathrm{~m}(3 \mathrm{ft})$ and $0.76 \mathrm{~m}(2.5 \mathrm{ft})$ in hoop diameter, respectively. Larger traps had a mean un-stretched mouth diameter of $18.8 \mathrm{~cm}$ 
$(\mathrm{SD}=2.53)$ and mesh width of $5.08 \mathrm{~cm}$, and smaller traps had a mean un-stretched mouth diameter of $15.8 \mathrm{~cm}(\mathrm{SD}=1.28)$ and mesh width of $2.54 \mathrm{~cm}$. Traps were held taut using two wood posts connected to the terminal hoops, and mouths were held open by tightening, then knotting the rope that opens them. This design allowed our traps to float and did not require that a ground stake be used to keep the mouth open. We placed flotation devices in all traps to prevent drowning of captures. We baited traps with a half-can of sardines in oil, in plastic bottles containing holes to allow for scent dispersal (Ernst 1965, Jensen 1998), and changed bait daily.

We checked traps daily. All captured turtles were identified, sexed, measured, marked using unique individual carapace notches (Cagle 1939), and released. We measured straight line carapace length (SCL) and width (SCW), plastron length and width, and body depth to the nearest $1.0 \mathrm{~mm}$ using calipers (Haglof, Madison, MS). We weighed individuals to the nearest 10 g using spring scales (Pesola, Baar, Switzerland). We determined sex using secondary sexual characteristics (Ernst and Lovich 2009).

We used paired randomization tests with 10,000 iterations to determine if number of captures and mean size of individuals differed between larger and smaller diameter hoop-net traps for Snapping Turtles and Painted Turtles. When sample sizes are relatively small such as in our study ( $n=32$ sites), randomization tests are an appropriate alternative to t-tests because the statistical distribution is derived from the randomized data, rather than assuming the data follow an underlying parametric distribution (Sokal and Rohlf 1995). The $P$-values for randomization tests are also intuitive, representing the proportion of trials with a mean difference between samples that is as or more extreme than what we obtained in the study. We inferred statistical significance at $\alpha=0.05$. 
Ponds served as the sampling unit in the analyses, with trap sizes paired within ponds. For each species, we calculated the total number of unique individuals captured per trap size. Thus, the same individual could be represented up to two times in the data, if it was captured in both trap sizes. For the size comparison, we used the mean SCL of unique individuals captured per trap size at each pond. We used histograms to assess differences in size class distributions based on trap diameter. Since the larger and smaller traps differed in mesh size $(5.08 \mathrm{~cm}$ and $2.54 \mathrm{~cm}$, respectively), we also investigated the potential influence of mesh size on captures for the small focal species. Specifically, we determined if number of captures and mean size of individuals differed between larger and smaller diameter hoop-net traps after excluding Painted Turtles $<8.0$ $\mathrm{cm}$ SCW, representing the maximum stretch width for the mesh of larger traps. Finally, we investigated the possibility that Snapping Turtle captures biased our Painted Turtle capture results. For this assessment, we computed the mean Painted Turtle catch per unit effort (CPUE) in traps with and without Snapping Turtles at each site, and then tested for a difference in mean CPUE. We performed statistical analyses using program R 3.3.2 (The R Foundation for Statistical Computing, Vienna, Austria).

\section{Results}

Total number of unique captures of Snapping Turtles and Painted Turtles was 98 and 283, respectively. Unique individuals captured per site of Snapping Turtles and Painted Turtles ranged from $0-18(\bar{x}=3.06 ; \mathrm{SE}=0.66)$ and $0-113(\bar{x}=8.84 ; \mathrm{SE}=3.94)$, respectively. The number of individual Painted Turtles recaptured 1-4 times were 66, 13, 4, and 3, respectively. Eight individual Snapping Turtles were recaptured once, but none were recaptured more than once. Only 1 Snapping Turtle was recaptured in the same trap as the previous capture. For 
individuals that moved, the straight line distance between capture locations ranged from 4-90 m $($ mean $=39 ; \mathrm{SE}=3.12)$. Eleven Painted Turtles were recaptured in the same trap as the previous capture. For individuals that moved, the straight line distance between capture locations ranged from $9-82 \mathrm{~m}($ mean $=31 ; \mathrm{SE}=1.63)$.

For Snapping Turtles, mean number of captures was significantly greater in larger diameter hoop-net traps $(P=0.014$; Table 1). For Painted Turtles, mean number of captures was significantly greater in smaller diameter hoop-net traps $(P=0.022)$. For Snapping Turtles, mean SCL was significantly greater in larger diameter hoop-net traps $(P=0.023)$, but all size classes were captured in both trap diameters (Figure 1a). For Painted Turtles, mean SCL was also significantly greater in larger diameter hoop-net traps $(P=0.019)$. In contrast to Snapping Turtles, the smallest and largest size classes were only captured in the smaller and larger diameter traps, respectively (Figure 1b). When Painted Turtles with SCW less than $8.0 \mathrm{~cm}$ were excluded, mean number of captures and mean SCL were not significantly different between hoop-net traps $(P=0.088$ and $P=0.564$, respectively). Mean CPUE of Painted Turtles was not significantly different for traps with and without Snapping Turtles $(P=0.424)$.

\section{Discussion}

The results of this study indicate that hoop-net trap diameter can influence capture success for freshwater turtles, with larger traps being more efficient for larger species, and vice versa. Though the study supported our hypothesis that hoop-net trap diameter would be positively correlated with the number of Snapping Turtles captured, we also found the opposite effect for Painted Turtles. However, our analyses suggest we cannot exclude the possibility that lower Painted Turtles captures in larger traps was caused by the potential for small individuals to 
escape through the mesh of larger traps, rather than by trap diameter. Other research does indicate that even smaller species than Painted Turtles, such as Spotted Turtles, have higher capture success with even smaller hoop-net traps (i.e., $0.14 \mathrm{~m}$ [0.5 ft] diameter; Howell et al. 2016), although no trap-choice experiment has been conducted to confirm this preference. We recommend that additional trap-choice experiments that use a broad range of hoop-net trap diameters, and a standardized mesh width of $\leq 2.54 \mathrm{~cm}$, be conducted to further clarify how species-specific capture success scales with trap diameter. Based on current evidence, smaller diameter traps should be used to maximize captures of smaller species, and vice versa.

Our study also indicates that hoop-net trap diameter can influence the size distribution of captures for both larger and smaller turtle species. Though this did not affect the range of sizes captured for our large focal species, and thus may not be perceived as a major bias, we did obtain different size distributions for our small focal species. It is unclear why we did not catch the largest individuals in smaller traps, but again the bias against catching the smallest individuals in larger traps could have been caused by the larger mesh size allowing for escapes. Previous studies report conflicting results on how size and species influence escape and catchability (Frazer et al. 1990, Flaherty et al. 2008, Brown et al. 2011, Mali et al. 2013). In addition, though the diameter of the trap does not limit ability to enter the trap, it might be easier for larger individuals to enter, and smaller individuals to escape, traps with a larger funnel and mouth opening. For example, Mali et al. (2014) found that increasing the ease of access through the mouth of horizontally throated traps (i.e., increasing the vertical open space of un-stretched mouths) resulted in 8 times as many captures for Red-eared Sliders. We note that no studies have tested whether circular or horizontally throated hoop-net traps are more effective for capturing turtles, and this should be investigated. 
In conclusion, our study indicates that diameter of hoop-net traps is an important sampling design consideration for freshwater turtle research and monitoring. If the same trap size is being used across all sites in a study, then the resulting data should be comparable. However, when comparing sampling data among studies, researchers should be aware that the diameter of hoopnet traps can influence both captures-per-unit-effort and the size distribution of individuals. In addition, researchers should consider using traps with smaller mesh to avoid escape of smaller turtles and multiple trap sizes if their study goal is to assess turtle communities.

\section{Acknowledgments}

This research was funded by the Natural Resources Conservation Service. This work also was supported by the USDA National Institute of Food and Agriculture, McIntire Stennis project WVA00117, and the West Virginia Agricultural and Forestry Experiment Station. J.T. Anderson was supported by the National Science Foundation under Cooperative Agreement No. OIA1458952 during manuscript preparation. We thank R. Wickiser, K. Levat, and K. Matthews for assisting with fieldwork. We are grateful to the West Virginia Division of Natural Resources, Potomac Audubon Society, and many private landowners for graciously allowing us to use their property for several days or weeks. We thank two anonymous reviewers for helpful suggestions that improved the quality of this manuscript. Capture and handling methods were approved by the West Virginia Division of Natural Resources (Permits 2016.173, 2016.174, 2017.013) and West Virginia University Institutional Animal Care Use Committee (Protocol 1603001197). Any use of trade, product, or firm names is for descriptive purposes only and does not imply endorsement by the U.S. Government. This is Scientific Article No. XXXX of the West Virginia Agricultural and Forestry Experiment Station, Morgantown, West Virginia, USA. 


\section{Literature Cited}

Brown, D.J., B. DeVolld, and M.R.J. Forstner. 2011. Escape from hoop nets by Red-eared Sliders (Trachemys scripta). Southwestern Naturalist 56:124-127.

Brown, D.J., M.M. Cochrane, and R.A. Moen. 2017. Survey and analysis design for wood turtle population monitoring. Journal of Wildlife Management 81:868-877.

Buckland, S.T., I.B.J. Goudie, and D.L. Borchers. 2000. Wildlife population assessment: Past developments and future directions. Biometrics 56:1-12.

Cagle. F.R. 1939. A system of marking turtles for future identification. Copeia 1939:170-173.

Campbell, S.P., J.A. Clark, L.H. Crampton, A.D. Guerry, L.T. Hatch, P.R. Hosseini, J.J. Lawler, and R.J. O'Connor. 2002. An assessment of monitoring efforts in endangered species recovery plans. Ecological Applications 12:674-681.

Chandler, H.C., D.J. Stevenson, J.D. Mays, B.S. Stegenga, W.H. Vaigneur, and M.D. Moore. 2017. A new trap design for catching small emydid and kinosternid turtles. Herpetological Review 48:323-327.

Davis, D.E. 1982. CRC handbook of census methods for terrestrial vertebrates. CRC Press, Boca Raton, Florida.

Ernst, C.H. 1965. Bait preferences of some freshwater turtles. Journal of the Ohio Herpetological Society 5:53.

Ernst, C. H., and J. E. Lovich. 2009. Turtles of the United States and Canada. $2^{\text {nd }}$ Edition. Johns Hopkins University Press, Baltimore, MD. 827 pp.

Flaherty, K.L., J.T. Anderson, and E.D. Michael. 2008. Adult survivorship and capture probability of the common snapping turtle (Chelydra serpentina). Journal of Herpetology 42:202-205 
Frazer, N.B., J.W. Gibbons, and T.J. Owens. 1990. Turtle trapping: preliminary tests of conventional wisdom. Copeia 1990:1150-1152.

Gamble, T. 2006. The relative efficiency of basking and hoop traps for painted turtles (Chrysemys picta). Herpetological Review 37:308-312.

Howell, H.J., D.T. McKnight, and R.A. Seigel. 2016. A novel method of collecting spotted turtles (Clemmys guttata). Herpetological Review 47:202-205.

Jensen, J.B. 1998. Bait preferences of southeastern United States coastal plain riverine turtles: Fish or fowl? Chelonian Conservation and Biology 3:109-111.

Koper, N., and R.J. Brooks. 1998. Population-size estimators and unequal catchability in painted turtles. Canadian Journal of Zoology 76:458-465.

Lagler, K.F. 1943. Methods of collecting freshwater turtles. Copeia 1943:21-25.

Lindeman, P.V. 2014. New wind in old bottles: Using modified hoopnets to catch bait-averse basking turtles. Herpetological Review 45:597-600.

Mali, I., D.J. Brown, M.C. Jones, and M.R.J. Forstner. 2013. Hoop Net Escapes and Influence of Traps Containing Turtles on Texas Spiny Softshell (Apalone spinifera emoryi) captures. Herpetological Review 44:40-42.

Mali, I., D.J. Brown, J.R. Ferrato, and M.R.J. Forstner. 2014. Sampling freshwater turtle populations using hoop nets: Testing potential biases. Wildlife Society Bulletin 38:580585.

Ream, C., and R. Ream. 1966. The influence of sampling methods on the estimation of population structure on Painted Turtles. American Midland Naturalist 75:325-338.

Sokal, R.R., and F.J. Rohlf. 1995. Biometry: The Principles and Practice of Statistics in Biological Research. 3rd Edition. Freeman, New York, NY. 887 pp. 
Sterrett, S. C., L. L. Smith, S. H. Schweitzer, and J. C. Maerz. 2010. An assessment of two methods for sampling river turtle assemblages. Herpetological Conservation and Biology 5:490-497.

Tesche, M.R., and K.E. Hodges. 2015. Unreliable population inferences from common trapping practices for freshwater turtles. Global Ecology and Conservation 3:802-813.

Tyre, A.J., B. Tenhumberg, S.A. Field, D. Niejalke, K. Parris, and H.P. Possingham. 2003. Improving precision and reducing bias in biological surveys: Estimating false-negative error rates. Ecological Applications 13:1790-1801.

Vogt, R.C. 1980. New methods for trapping aquatic turtles. Copeia 1980:368-371.

Yoccoz, N.G., J.D. Nichols, and T. Boulinier. 2001. Monitoring of biological diversity in space and time. TRENDS in Ecology \& Evolution 16:446-453. 
Table 1 Summary data for number and mean size of Snapping Turtles (Chelydra serpentina), Painted Turtles (Chrysemys picta), and Painted Turtles with a straight line carapace width (SCW) $>8.0 \mathrm{~cm}$ captured in comparatively large $(0.91 \mathrm{~cm})$ and small $(0.76 \mathrm{~cm})$ diameter hoop-net traps. For this study, we sampled 32 ponds in West Virginia, with each pond sampled using 5 large and 5 small hoop-net traps. Data include total number of captures, mean number and standard deviation of captures per pond, and mean and standard deviation of straight line carapace length (SCL) among ponds. Unique individuals were included in both trap size data sets if they were captured in both trap sizes. $P$-values represent the results of paired randomization tests.

\begin{tabular}{|c|c|c|c|c|c|c|c|c|}
\hline \multirow[t]{2}{*}{ Species } & \multirow[t]{2}{*}{ Variable } & \multicolumn{3}{|c|}{ Large traps } & \multicolumn{3}{|c|}{ Small traps } & \multirow[t]{2}{*}{$P$} \\
\hline & & $n$ & Mean & $\mathrm{SD}$ & $n$ & Mean & SD & \\
\hline \multirow[t]{2}{*}{ Snapping Turtle } & Captures & 67 & 2.1 & 2.6 & 36 & 1.1 & 1.9 & 0.014 \\
\hline & SCL & & 277 & 43.8 & & 247.9 & 35.9 & 0.023 \\
\hline \multirow[t]{2}{*}{ Painted Turtle } & Captures & 95 & 3 & 7.5 & 231 & 7.2 & 18.8 & 0.021 \\
\hline & SCL & & 139.2 & 12.8 & & 125.7 & 25.8 & 0.019 \\
\hline \multirow[t]{2}{*}{$(\mathrm{SCW}>8.0 \mathrm{~cm})$} & Captures & 93 & 2.9 & 7.3 & 163 & 5.1 & 12.4 & 0.088 \\
\hline & SCL & & 139.2 & 12.8 & & 136 & 12.6 & 0.564 \\
\hline
\end{tabular}




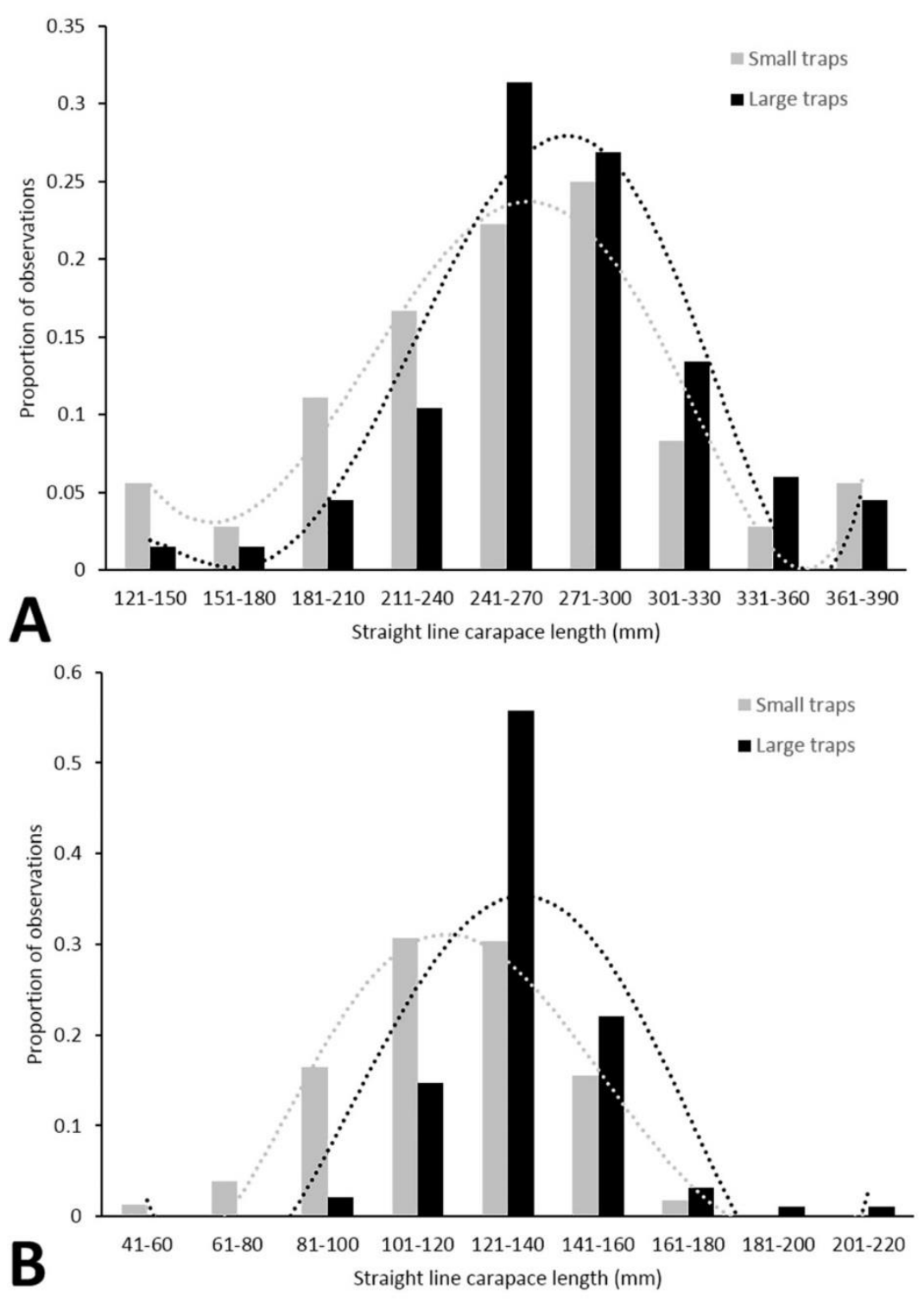

Figure 1 Size class distribution for (A) Snapping Turtles (Chelydra serpentina) and (B) Painted Turtles (Chrysemys picta) captured in comparatively large $(0.91 \mathrm{~cm})$ and small $(0.76 \mathrm{~cm})$ diameter hoop-net traps. For this study, we sampled 32 ponds in West Virginia, with each pond sampled using 5 large and 5 small hoop-net traps. Dotted lines represent the size distribution curves based on a fifth-degree polynomial. 